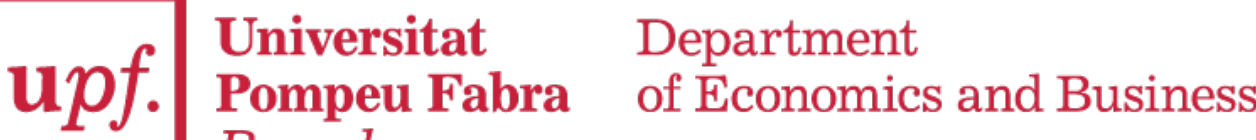 Barcelona
}

\author{
Economic Working Paper \\ Series Working Paper No. 1733
}

Riding out of a financial crisis: The joint effect of trust and corporate ownership

Mario Daniele Amore and Mircea Epure

July 2020 


\title{
Riding Out of a Financial Crisis: The Joint Effect of Trust and Corporate Ownership
}

\author{
Mario Daniele Amore \\ Bocconi University and CEPR \\ mario.amore@unibocconi.it
}

\author{
Mircea Epure \\ Universitat Pompeu Fabra and BGSE \\ $\underline{\text { mircea.epure@upf.edu }}$
}

July $13,2020^{*}$

Journal of Comparative Economics, forthcoming

\begin{abstract}
We study how generalized trust shapes the ability of firms with different ownership forms to obtain trade financing and perform during a financial crisis. Exploiting geographic variations in trust across Italian regions and the occurrence of the 2008-09 financial crisis in a difference-indifferences setting, we show that generalized trust makes family firms less able to obtain trade financing during the crisis. This finding maps into performance results: trust alleviates the negative effect of a crisis for non-family firms, while it aggravates the negative effect for family firms. This latter result depends crucially on a firm's corporate governance: trust does not harm family firms whose board is open to non-family directors. Collectively, our findings illustrate how culture interacts with corporate attributes in shaping a firm's prospects.
\end{abstract}

Keywords: trust; trade financing; family firms; financial crisis; performance

JEL classification: G32; G34; Z10

\footnotetext{
${ }^{*}$ We thank the Editor, Timur Kuran, two anonymous reviewers, Benito Arruñada, Morten Bennedsen, Vicente Cuñat, Andrew Ellul, Javier Gomez-Biscarri, Luigi Guiso, Luigi Pascali, José Luis Peydró, Andrea Polo, Carlos Serrano, Daniel Wolfenzon, and seminar participants at U. Pompeu Fabra, Cass Business School, U. Amsterdam, ESADE Business School, U. Bologna, U. Padua, and participants at the Society for Institutional \& Organizational Economics (Montréal), the Family Business and Corporate Control Workshop (Milan), the European Accounting Association Congress (Valencia), the Academy of Management (Atlanta), and the International Corporate Governance Society (Shanghai) for useful comments and suggestions. We also thank Guido Corbetta and Fabio Quarato for support with the data. This work received support from the Spanish Government through the grants ECO2014-57131-R, ECO2017-85763-R and SEV-2015-0563. Usual disclaimers apply.
} 


\section{Introduction}

There is a large evidence that financial crises harm companies by limiting the availability of bank credit (Campello et al. 2010; Kahle and Stulz 2013). An important question within this literature is whether family firms - a common organization around the world (Anderson and Reeb 2003; Faccio and Lang 2002) - are better or worse positioned than non-family firms to deal with financial crises. ${ }^{1}$

The ability of companies to weather a financial crisis depends not only on firm-specific characteristics such as financial strength (Duchin et al. 2010) but also on contextual elements such as the cultural values in the area where firms operate. ${ }^{2}$ Along this line, Levine et al. (2018) show that, by fostering cooperation among business partners, generalized trust raises the amount of trade financing available to companies. The key mechanism here is that, by reflecting beliefs of trustworthiness in others' behavior (Sapienza et al. 2013), trust improves contractual relationships (Bromiley and Cummings 1995; Dyer and Chu 2003). ${ }^{3}$

Unfortunately, existing assessments of the role of trust for the financing ability of firms have largely ignored the role of ownership types. Stacchini and Degasperi (2015) make a useful step in this direction, but their work only looks at the supply of bank debt to family firms and non-family firms during a crisis. We contribute to this literature by focusing on trade financing, which represents a primary source of financing when bank credit dries up (Garcia-Appendini and Montoriol-Garriga 2013), as well as on firm performance. More specifically, we address the novel question of whether family firms are better or worse than non-family firms at accessing

\footnotetext{
${ }^{1}$ Some works show that family firms secure more funds during a crisis (e.g. Lagaras and Tsoutsoura 2015); others show that family firms invest less and underperform as compared to non-family firms (e.g. Lins et al. 2013).

${ }^{2}$ Relatedly, existing studies have explored the role of trust during turbulent times (Sangnier 2013).

${ }^{3}$ The notion that trust can ease market transactions goes back to Arrow (1972), who wrote that "virtually every commercial transaction has within itself an element of trust." A large research shows that trust promotes stock market participation (Guiso et al. 2004, 2008), delegation of decision rights (Bloom et al. 2012; Gur and Bjornskov 2017), trade flows (Guiso et al. 2009), trade financing (Levine et al. 2018), and venture capital investment (Bottazzi et al. 2016) - all outcomes that require dealing with counterparts.
} 
this alternative funding source and sustaining performance in a crisis as a function of the level of generalized trust in the geographic area of the firm's headquarter.

The effect of family ownership on trade financing during crises is theoretically unclear. On the one hand, family ties provide networking advantages (Amore and Bennedsen 2013; Bertrand and Schoar 2006; Bunkanwanicha et al. 2013), which could facilitate the access to trade financing. On the other hand, family firms - especially those led by family heirs - tend to display poorer corporate governance (Bloom and Van Reenen 2007) and greater informational opaqueness (Anderson et al. 2009), which can be costly in tightening credit markets. In a hightrust context, impersonal market transactions tend to be more prominent and entrenchment is punished more severely (e.g. Tabellini 2010); hence, suppliers facing greater uncertainty and binding financial constraints due to a crisis would favor firms with sound corporate governance. These arguments suggest that generalized trust hampers the ability of family firms to reap the benefit of networking and exacerbate the downside of opaqueness as they strive to access trade financing in hard times.

We conduct the analysis on a panel dataset of 14,337 firms in Italy from 2004 to 2009 (a period including both non-crisis and crisis years). The Italian context benefits from welldocumented differences in generalized trust across regions, whose origins date back to the Middle Ages (Guiso et al. 2016; Putnam 1993) and are largely exogenous to current firm outcomes. Our analysis identifies the heterogeneous response to the financial crisis by companies that have different owners but that are located in the same (high or low trust) area. In particular, we employ a difference-in-differences approach in which the longitudinal variation is given by the crisis years of 2008-09 and the cross-sectional variation is given by the level of generalized trust in the region of headquarter of family and non-family firms. 
We find that a crisis makes family firms less able to obtain trade financing in areas where trust is high. The financial crisis has a negative effect on the trade financing of both family and non-family firms, ranging between 3.5 and 4.3 percentage points with respect to the average value; however, for family firms trust amplifies the negative effect by 0.8 percentage points. Going beyond the comparison between family and non-family firms, we study the role of corporate governance within family firms. Results show that the negative effect of trust on trade financing during a crisis is significant for family firms with only family directors; by contrast, trust does not alter the effect of financial crisis on the trade financing of family firms with any non-family director. This heterogeneity is consistent with the view that during a crisis informational opaqueness becomes costlier in high-trust contexts - a cost which family firms with boards open to non-family directors are able to mitigate. ${ }^{4}$

Next, we focus on firm performance. As expected, the financial crisis had a negative effect on operating profitability (i.e. return on assets, ROA). Moreover, trust reduces this negative effect - though this is true only for non-family firms. For family firms, trust aggravates the negative effect of the financial crisis on profitability. The direct effect of the crisis corresponds to a 1.3 to 2 percentage points drop from the average ROA of $9 \%$; while trust reduces this drop by 0.4 percentage points for non-family firms, it exacerbates it by 0.3 percentage points for family firms. Similar to trade financing, the negative profitability effect is absent for family firms that feature non-family members in the board of directors.

These findings hold controlling for time-invariant heterogeneity at the firm level (thus removing fixed differences between family and non-family firms) and for multiple sources of omitted factor bias. Moreover, we validate the assumption of parallel trends in profitability before the crisis necessary for the causal interpretation of our results. Finally, we address

\footnotetext{
${ }^{4}$ For evidence on the importance of non-family directors in family firms see, e.g., Anderson and Reeb (2004).
} 
concerns of endogeneity in family ownership by exploiting the historical variations in managerial practices across Italian provinces provided by the US Productivity Program (Giorcelli 2019).

Recent works have analyzed the role of trust during periods of credit contraction. Lins et al. (2017) find a positive effect of firm-level social capital and trust on stock returns during a financial crisis, whereas Levine et al. (2018) show that trust increases trade financing thus alleviating the negative effect of liquidity crises on firm activities. Our contribution is to document the underexplored complementarity between cultural values, and firm ownership and governance structures in determining which firms are better positioned to perform during a crisis. As such, we move beyond Stacchini and Degasperi (2015), who show that family firms face lower bank loan spreads in low-trust areas. Here our contribution is threefold. First, we study trade financing, which represents a key funding source during financial crises (GarciaAppendini and Montoriol-Garriga 2013). Second, our identification separates the effect of trust from other regional characteristics and also accounts for the endogeneity of family ownership through an historical instrument. Third, we explore the important role of corporate governance in shaping the nexus between trust and crisis - and show that boards drive significant differences in our results.

Our work also relates to a literature on the interaction between institutional characteristics and corporate governance (e.g. Cosset et al. 2016). While this research has shown the importance of governance quality to overcome financial shocks, the question of how firms' ownership interacts with cultural values remains largely underexplored. By showing a significant intertwinement between the identity of firm owners and generalized trust, our findings expand the literature on the importance of cultural values for firms' organization (Bloom et al. 2012; Bottazzi et al. 2016; Chami and Fullenkamp 2002; Hilary and Huang 2015; La Porta et al. 1997). 
Accounting for institutional (e.g. Burkart et al. 2003; Mueller and Philippon 2011) and cultural factors (e.g. Amore 2017; Bertrand and Schoar 2006) helps to explain the diffusion of family businesses and understand when these firms perform better or worse than others. For instance, Amit et al. (2015) show that family firms outperform in areas where institutional efficiency is high. Miller et al. (2017) show that family-managed firms outperform other family firms in areas where family values are counteracted by market values. Our work contributes to this literature by showing the role of ownership and governance attributes in the wake of a financial shock.

\section{Data and variables}

\subsection{Measuring generalized trust}

In the past twenty years, the concept of social capital has gained significant traction in the economics literature due to its far-reaching implications for many individual and macro-level outcomes. At the same time, social capital is a broad concept whose ambiguous definitions have generated some confusion. While the literature still lacks a clear-cut definition, we accord with Guiso et al. (2011) in considering social capital as civic capital, i.e. "a set of persistent and shared beliefs and values that help a group overcome the free rider problem in the pursuit of socially valuable activities." This perspective suggests that generalized trust is a specific measurable belief pertaining to social capital: it captures the extent to which individuals belonging to a given community are willing to perform an action beneficial to that community given their expectation that others will do the same. ${ }^{5}$

\footnotetext{
5 Thus, generalized trust is broader in nature than bilateral trust (i.e. who trust whom). For a work on bilateral trust, see Guiso et al. (2009).
} 
How can we measure generalized trust? In the economics literature, the two main approaches are laboratory experiments and large-scale surveys. We follow the latter approach and use the World Values Survey (WVS), which compiles individual-level surveys conducted across and within countries on a wide variety of topics that revolve around the beliefs, values, and motivations of people. Given its high degree of detail and comparability across regions, the WVS has become one of the most common sources for measuring cultural values around the world (Knack and Keefer 1997; La Porta et al. 1997; Guiso et al. 2008; Alesina and Giuliano 2015; Levine et al. 2018). ${ }^{6}$ Similar to these studies, we measure generalized trust by using the answer to the following specific question: "Generally speaking, would you say that most people can be trusted, or that you can't be too careful in dealing with people?" This question has three possible responses: (1) most people can be trusted; (2) you can't be too careful in dealing with other people; and (3) I don't know. Similar to Levine et al. (2018), we measure trust three years before the crisis (i.e. using the 2005 WVS wave) and expect it to remain stable over long periods of time. Indeed, cultural norms show stable patterns in human behavior and thus can be considered exogenous to the current decision-making processes that they influence (see Alesina and Giuliano 2015, and Guiso et al. 2016 for related discussions). ${ }^{7}$ One concern with this assumption is that trust may have been influenced by the financial crisis. To overcome this criticism, we will show that our results hold if we use a measure of trust after the crisis.

We calculate trust within each of the 20 regions of firm headquarter by taking the percentage of WVS respondents who indicate that "most people can be trusted."

\footnotetext{
${ }^{6}$ See Sapienza et al. (2013) for a validation of WVS-based trust with experimental data.

${ }^{7}$ Further validating that trust is persistent over time, Bottazzi et al. (2016) show that the correlation across different waves of the Eurobarometer dataset is often 0.9.

${ }^{8}$ Changes in the region of headquarter among are rare, and our results are unaffected by these cases.
} 
the median split of the resulting variable to define a dummy that takes the value of one for regions with "high-trust", and zero otherwise.

\section{Insert Figure 1 about here}

Summary statistics in Table 1 show that the average level of trust in the full sample is 0.33 (standard deviation of 0.06). For the definition of the high-trust indicator we use the median value of 0.36 . How does this value compare with other European countries? Generalized trust amounts to 0.34 in Austria, 0.35 in Germany, and 0.36 in Spain. Conversely, Northern European countries such as the Netherlands and Denmark display higher trust values, equal to 0.60 and 0.67, respectively. However, Italy presents significant differences across the North and South of Italy (see Figure 1), as well as across regions in areas sharing similar institutional and macroeconomic conditions (Guiso et al. 2016). Figure 1 shows how generalized trust differs by more than one standard deviation between Lombardy (Milan) and Veneto (Venice). In the robustness analysis, we check that our results are robust to defining trust in alternative ways.

\subsection{Firm-level data}

We start from the population of Italian firms with revenues above 20 Million Eur as of 2007. Using filings from the Italian Chambers of Commerce, we classify a company as "family firm" if at least $50 \%$ of its equity is in the hands of a family (or $25 \%$ if the company is listed). ${ }^{9}$ This approach follows existing studies in the Italian context (e.g. Amore et al. 2014; Miller et al. 2013). Following Laeven and Valencia (2013), we create a dummy variable that takes the value

\footnotetext{
$997 \%$ of our sample is formed by privately-held firms.
} 
of one during the two core years of the financial crisis in Italy (2008-09), and zero for the precedent years (i.e. 2004-07). ${ }^{10}$

Using accounting data (drawn from Bureau van Dijk), we follow Levine et al. (2018) and compute trade financing as the accounts payable at the end of period $t$ minus accounts payable at the beginning of period $t$, divided by cost of goods sold during period $t .{ }^{11}$ Similar again to Levine et al. (2018) we restrict this measure to manufacturing firms. To measure performance, we compute return on assets (ROA) as the ratio of earnings before interest, taxes and depreciation (EBITDA) to total assets (Bennedsen et al. 2007; Perez-Gonzalez 2006). We also compute the natural logarithm of total assets to control for firm size, the ratio of cash holdings to total assets to control for liquid assets, and the ratio of total debt to total assets to measure the use of debt in a firm's capital structure.

Insert Table 1 about here

After removing missing values in the variables described above, our sample contains 14,337 unique firms for a total of 71,605 observations. Of these, around $65 \%$ correspond to family firms - a figure consistent with the well-known pervasiveness of family ownership in Italy. Table 1 provides summary statistics for these key variables, while complete definitions are provided in Table A1. As argued, existing works show that family ownership is more common when generalized trust is low (Amore 2017; Bertrand and Schoar 2006). From a descriptive purpose, we investigated the differences between family firms in high- and low-trust areas. Our results (untabulated) suggest that family firms in high-trust areas are larger, they have more equity in their capital structure, and hold more cash and equivalent securities.

\footnotetext{
${ }^{10}$ Our results are robust to excluding 2004 or including 2010 as an additional crisis year.

${ }^{11}$ Dividing by total assets instead of cost of goods sold does not alter our results.
} 


\section{Trade financing}

Our first goal is to estimate how trust influences the impact of the financial crisis on the firm's ability to access alternative financing sources. To this end, we estimate the following model:

$$
\text { Trade financing }_{i, r, t}=\alpha+\beta_{1} \text { Crisis }_{t}+\beta_{2} \text { High-trust } t_{i, r}+\beta_{3} \text { High-trust }_{i, r} \times \text { Crisis }_{t}+\mathbf{X}_{i, t} \eta+v_{i}+\varepsilon_{i, t} .
$$

where the dependent variable is trade financing for a firm $i$ headquartered in region $r$ at time $t$. The key explanatory variables are the dummy equal to one for the financial crisis period (and zero for the non-crisis period), and its interaction with the dummy identifying whether the firm is headquartered in a high-trust region or not. Our specification is essentially a difference-indifferences model in which Crisis $s_{t}$ gives the longitudinal variation around the financial crisis, and High-trust $t_{i, r}$ is a binary treatment. We include firm fixed effects to control for unobserved heterogeneity across firms. Because trust does not vary over time, it is perfectly collinear with the firm fixed effects and thus we exclude it from our estimation. Following Levine et al. (2018), depending on the specification, we include a set of time-varying firm characteristics (i.e., firm size, long-term debt ratio and ROA) that can influence trade financing. Standard errors are computed by clustering at the firm level to adjust for both heteroskedasticity and serial correlation by firm.

In equation (1) the coefficient of interest is $\beta_{3}$, which establishes whether firms in hightrust regions accessed trade financing differently during the financial crisis as compared to firms in low-trust regions. We expect opposite results depending on a firm's ownership. For nonfamily firms, we expect this coefficient to be positive: high-trust alleviates the negative effect of the crisis on trade financing. However, for family firms we expect this coefficient to be negative. 
We start by estimating equation (1) separately for family firms and non-family firms, and then we estimate a triple interaction model on the full sample.

\section{Insert Table 2 about here}

Results in Table 2 reveal that the financial crisis has a negative direct effect of trade financing for both family and non-family firms. In Columns (3)-(5), which include the full set of controls, this effect ranges between 3.5 and 4.3 percentage points with respect to the average trade financing. Yet, trust amplifies by 0.8 percentage points the negative effect of the financial crisis on trade financing for family firms; by contrast, there is a positive but insignificant effect for non-family firms. ${ }^{12}$

One question concerns the need to shift from bank to trade financing in a crisis. To address this question, we split the sample between firms which have experienced an increase or no change (Column 6) vs. a decrease (Column 7) in the average level of bank debt to total assets in the crisis period with respect to the pre-crisis period. We find that our previous results are stronger for those firms that experienced a decrease in bank debt (i.e. arguably required more alternative financing): among those, family firms headquartered in a high trust area were less able to resort to trade financing. ${ }^{13}$

We now go beyond the raw comparison between family and non-family firms and probe into the role of corporate governance within the sample of family firms. Here we ask whether the lower trade financing for family firms in a high-trust area during the crisis may vary depending on whether or not the firm has any non-family director. To this end, we use two variables: (1) the

\footnotetext{
${ }^{12}$ In Column (5) the Crisis $\times$ Family interaction reveals that family firms have less trade financing also in low-trust regions. However, the triple High-trust $\times$ Crisis $\times$ Family interaction confirms that there is an aggravating effect of trust that makes trade financing even less available to family firms.

${ }^{13}$ The direct effect of the crisis is significant in both subsamples. This is potentially attributable to the fact that even for firms in Column (6), i.e. those that did not experience a decrease in bank debt, the financial crisis created a significant financial deficit and made it necessary to access additional non-bank debt.
} 
share of family board members to the total number of board members; (2) a dummy variable equal to one if the firm only has family CEOs, and zero otherwise. We then estimate the model in equation (1) on the subsamples corresponding to firms that employ only family directors or any non-family director; next, we add the condition of any family CEOs. Table 3 shows that the negative effect of the financial crisis on trade financing is exacerbated in high-trust only for those family firms that exclusively employ family directors (and family CEOs).

Insert Table 3 about here

Finally, we explore how our results are driven by the industry reliance on trade financing by constructing two subsamples around the median value of trade financing in the 2-digit manufacturing industries. Results in Table 4 show that the negative effect of the financial crisis on the access to trade financing is more precisely estimated and larger for family firms in hightrust contexts and operating in industries highly reliant on trade financing. In summary, when formal financing is scarce generalized trust makes trade financing less available to family firms as compared to non-family firms.

Insert Table 4 about here

\section{Firm performance}

\subsection{Results}

We now investigate how generalized trust affects the impact of the financial crisis on firm profitability by estimating the following model:

$$
\text { ROA }_{i, r, t}=\alpha+\beta_{1} \text { Crisis }_{t}+\beta_{2} \text { High-trust }_{i, r}+\beta_{3} \text { High-trust }_{i, r} \times C r i s i s_{t}+\mathbf{X}_{i, t} \eta+v_{i}+\varepsilon_{i, t}
$$

where the dependent variable is the ROA of firm $i$ headquartered in region $r$ at time $t$. 
The key explanatory variables are the dummy equal to one for the financial crisis period (and zero for the non-crisis period), and its interaction with the dummy identifying whether the firm is headquartered in a high-trust region. As in equation (1), we include firm fixed effects to control for unobserved heterogeneity across firms. Because trust does not vary over time, it is perfectly collinear with the firm fixed effects and thus we exclude it from our estimation. We include a set of time-varying controls that may correlate with performance: firm size, cash holdings and total debt defined as the ratio of total debt to total assets. To establish the effect of the crisis on firms outcomes, we start by estimating equation (2) separately for family firms and non-family firms, and then estimate a triple interaction model.

Insert Table 5 about here

Results in Columns (1)-(2) of Table 5 show that the financial crisis of 2008-09 had a negative and significant effect on firm profitability, with a slightly larger magnitude for family businesses. In economic terms, the crisis induced a ROA decrease between 1.3 and 1.4 percentage points (corresponding to a drop of $14 \%$ to $16 \%$ from the average ROA of $9 \%$ ). Trust significantly amplifies the effect of the crisis. Importantly, however, this effect is positive (and $10 \%$ significant) only for non-family firms (Column 1); the sign reverses (and becomes $5 \%$ significant) for family firms (Column 2). In economic magnitude, trust reduces the negative effect of the crisis on ROA by 0.4 percentage points for non-family firms, while it exacerbates the ROA decline by 0.3 percentage points for family firms.

As shown in Columns (3)-(4), this finding is robust to controlling for time-varying firmlevel controls. Results indicate that the interaction between crisis and high trust is positive and significant at the 5\% level. In Column (5), we estimate a model with a triple interaction on the full sample. We find, consistent with Lins et al. (2013), that the performance of family firms is 
hit harder by the crisis across all trust levels as indicated by a negative and significant coefficient of the interaction between crisis and family firm dummies. Yet, supporting our previous findings, there is an aggravating effect of trust, as the triple interaction between crisis, high trust and family ownership displays a negative coefficient significant at the $1 \%$ level.

We examine the heterogeneity of these findings depending on the level of family involvement in governance positions. Table 6 shows that trust aggravates the negative effect of the crisis for firms with more family-centric boards. Columns (1)-(2) reveal that while the financial crisis has a negative effect of around 1.8 percentage points on profitability, trust exacerbates this effect by 0.5 percentage points for family firms with only family directors, which experience a total negative effect of 2.3 percentage points (or a total decrease of $26 \%$ from the average ROA of 9\%). By contrast, for family firms with any non-family directors, trust does not significantly influence the effect of the crisis on profitability. In Columns (3)-(4) we find the same results when considering only firms with family CEOs, and splitting the sample between firms that exclusively employ family directors and those with non-family directors.

Insert Table 6 about here

\subsection{Trust vs. macroeconomic, institutional and industry conditions}

Geographic heterogeneity. In Column (1) of Table A2 we augment our specification with a set of triple interactions between the crisis dummy, the family firm dummy and macro-area dummies (defined as north-east, north-west, center and south regions of Italy) in order to narrow down our identification within homogeneous areas. Our findings are largely robust to the inclusion of such interaction terms. ${ }^{14}$

\footnotetext{
${ }^{14}$ In untabulated regressions we check that our results hold including the interactions between macro-area dummies with year dummies.
} 
Regional economic activity. We show that our results hold when controlling for the triple interactions between the crisis dummy, the family firm dummy and regional-level annual GDP growth (Column 2), and employment rates (Column 3) from the ISTAT (Italian National Statistics Office). Our results are thus robust to accounting for differential response of firms to the crisis depending on the economic conditions in their region of headquarter.

Institutional quality. Another potential concern is that trust may correlate with elements of institutional quality, which may partly capture accountability with similar effects to those of trust on corporate outcomes during crisis times. To accommodate this concern we check that adding the triple interaction between the crisis dummy, the family firm dummy and the length of judiciary trials (a common proxy for the quality of legal enforcement; see e.g. Guiso et al. 2004) does not affect our results (Column 4). In addition, in Column (5) we add the triple interaction with the regional level of corruption, obtained from ISTAT. These results validate that our trust results are not driven by economic or institutional characteristics.

Industry structure and economic activities. In Column (6) we control for the revenue-based Herfindahl-Hirschman index (HHI) and its interaction with crisis and high-trust dummies in order to rule out the concern that our results are confounded by a different exposure of family and non-family firms to competition by trust levels. In Column (7), we account for industry structure and competitive dynamics at the regional level by including a set of interactions between crisis, high-trust, the ratio of firms per thousand inhabitants, the number of employees per firm, and the ratio of net firm entry (i.e. the ratio of entry rate minus the ratio of firms' mortality rate within 5 years; from ISTAT). In Column (8), we control for the interaction between 2-digit industry dummies and the crisis dummy. Overall, these tests reduce the concern that our results are explained by differences in industry structure across regions, which may in turn correlate with trust (Cingano and Pinotti 2016). 


\subsection{Parallel trends and dynamics}

As shown in Section 2, family firms in high- and low-trust are cross-sectionally different in size, capital structure and other characteristics. These differences raise the question of whether the parallel trend assumption - necessary for the causal interpretation of our results - is satisfied. This assumption maintains that family and non-family firms in high and low-trust regions exhibit parallel trends in profitability prior to the financial crisis. We explore the validity of this assumption using an intuitive illustration based on the pre-sample years that we have starting from 2000. In Figure 2 we show the average ROA for family and non-family firms in the precrisis years until 2007, by high and low trust areas. As illustrated, the average profitability trends for the four groups tend to be largely parallel in the years leading up to the financial crisis.

Insert Figure 2 about here

Next, we explore the dynamics of our regression results by replacing the crisis dummy in our specification in Column (5) of Table 5 with a set of dummies for each year in our sample period (using 2004 as reference year), which we interact with the high-trust and the family firm dummies, while maintaining the set of controls and the firm fixed effects. Figure 3 illustrates the coefficients of the triple interaction between the year dummies, high-trust and the family firm dummy together with the $95 \%$ confidence interval.

Insert Figure 3 about here

The graph shows that the interaction terms between year dummies, high-trust and the family firm dummy are insignificant in all of the pre-crisis years (until 2007). In other words, in high-trust areas the profitability of family firms did not significantly differ from that of non- 
family firms. Together with the evidence above, this finding is important to reduce concerns of diverging trends in profitability before the financial crisis. Focusing on the crisis years (2008-09) the graph illustrates the negative and significant effects, confirming that during crisis period, family firms in high-trust were worse off as compared to non-family firms.

\subsection{Endogeneity of family ownership}

Family firms can differ from non-family firms in ways that may not be observable to us. Our specifications systematically control for firm fixed effects, thus absorbing all the observed and unobserved sources of heterogeneity that are constant over time. Moreover, we control for a number of time-varying firm characteristics that capture several structural differences across firms. Here we deal with endogeneity concerns using a two-stage least square regression.

To build this identification we need a variable that exogenously influences the likelihood of family firm without affecting at the same time current firm profitability. To this end, we draw on the empirical approach in Giorcelli (2019). As part of the Marshall Plan, the US organized the Productivity Program (1952-1958) which consisted of training trips for managers of European manufacturing firms to study modern managerial practices and purchase (using subsidized loans) US technologies. We posit that an exogenous influx of modern managerial practices in certain areas may have spurred a long-lasting openness to professional management and in turn a less tight control of families over time. This effect can stem from a direct effect of the program on the firms involved and from peer effects whereby certain managerial practices and knowledge transfer spread out more in areas with firms involved in the program due to networking, imitation and learning. Empirically, a desirable feature is that the implementation of the program featured geographic discontinuities. As discussed in Giorcelli (2019), the US authorities first identified five pilot regions (Lombardia, Veneto, Toscana, Campania and Sicilia) for a small- 
scale implementation before applying the program at the national level. Yet, due to a budget cut such pilot implementation was narrowed to one province for each of the five pilot regions. ${ }^{15}$

Our dataset contains foundation year, industry and province of headquarter which we can use to track down the subsample of manufacturing firms operating in the pilot regions. We have 307 manufacturing firms corresponding to 1,608 observations founded prior to 1951 (i.e. one year before the program started). ${ }^{16} \mathrm{We}$ then create an indicator equal to one if the firm is headquartered in a province treated by the program, or zero for provinces within a pilot region but not in a treated province. ${ }^{17}$ This indicator is used as an instrument to estimate the likelihood that a firm has maintained family control or not. Results reported in Table 7 provide support to the notion that firms in areas exposed to the program feature a lower likelihood of family ownership.

Insert Table 7 about here

Then, we employ the predicted values of family control to estimate our baseline model including trust, crisis and the interaction with family ownership. Column (2) of Table 8 shows that our main results hold once we employ the predicted values of family ownership. In Column

\footnotetext{
${ }^{15}$ To be eligible for the program, firms had to founded be headquartered in any of these five provinces, they had to operate in manufacturing industries, had between 10 and 250 employees and had to file a balance sheet from 1949 to 1951. There were 6,065 eligible firms and, among those, 3,624 applied for the program. See Giorcelli (2019) for more details. The selection of "experimental" provinces does not happen to be a function of a province's medieval roots (and thus a province's social capital). Indeed, this selection was motivated mostly by budget considerations.

${ }^{16} \mathrm{We}$ restrict the sample to firms operating at the time of the program to ease the interpretation of the treatment effect. Indeed, enlarging the sample to firms of all ages runs the risk of confounding the treatment with other potential spillover effects not directly related to the instrument, which may have had impacted on ownership forms in ways difficult to control for with our data.

${ }^{17}$ As such, the indicator varies across provinces (the instrument's level of variation) and within region (the level of variation of trust).
} 
(1) we report our baseline OLS model estimated on the same subsample for comparison purposes. $^{18}$

Insert Table 8 about here

\subsection{Robustness checks}

Placebo and post-crisis trust. We estimate our model after assigning randomly trust to regions of firm headquarter. Results in Column (1) of Appendix Table A3 show that, consistent with a causal interpretation, such placebo trust does not have any significant effect on firm performance. Another concern is that the crisis may have altered the level of trust. ${ }^{19}$ In line with Bottazzi et al. (2016) and Levine et al. (2018), we do not expect significant variations in generalized trust over time. However, to address this concern we measure generalized trust using the European Social Survey wave from 2012 (that is, a few years after the peak of the financial crisis). ${ }^{20}$ Results in Column (2) support our findings.

Alternative measures of firm performance. In Column (3) we use as dependent variable a firm's total factor productivity (TFP), computed as the residuals from regressing the natural logarithm of revenues on the natural logarithm of employees, the natural logarithm of the value of fixed assets, year and industry dummies. In Column (4) we use the return on sales (ROS) defined as the firm's net profit divided by revenues. In Column (5) we use the logarithm of

\footnotetext{
${ }^{18}$ In interpreting our results, one may wonder whether the instrument caused larger first-stage variations in those areas that were poorly endowed with pre-existing social capital (and, in turn, already more open to professional management). In contrast, areas rich in social capital may have been less affected by the instrument. The limited sample used to carry out this analysis prevents us from exploring the heterogeneity behind the main effect. That said, it is important to keep in mind that our 2SLS findings have a "local" interpretation that may not extend to the average company.

${ }^{19}$ Sapienza and Zingales (2012) show that individuals trusted less the financial sector after the collapse of Lehman Brothers.

${ }^{20}$ The European Social Survey is a large-sample survey covering European countries and containing information on social values and cultural norms. In this robustness check we employ the $6^{\text {th }}$ round, which refers to the year 2012. The survey question used to measure trust is identical to the one in the WVS.
} 
revenues-to-assets to measure how efficiently a firm uses its assets to generate revenues. Results from these tests are largely consistent with our ROA findings.

Computation of residuals. Until now, we have clustered standard errors at the firm level. We corroborate our results by clustering errors at the region level (Column 6), i.e. the level of aggregation of our trust variable, and by two-way clustering errors at region and year (untabulated).

Additional firm-level controls. We interact all firm-level controls with crisis and high-trust dummies to account for the heterogeneous responses to crisis; we also include the triple interaction with firm age (Column 7). This test mitigates the concern that more successful family firms in high-trust regions evolve to non-family firms at a faster rate and that this may bias the quality distribution of family firms in the high and low-trust subsamples.

Endogenous ownership changes. Ownership structures tend to be stable over time. However, in Column (8) we remove observations where the fraction of family equity capital changes over time. Excluding them is useful to mitigate concerns that our results may be influenced by heterogeneous changes in ownership in high and low-trust areas. Our results remain unaffected.

Exposure to different bank types. One can expect family firms to use their networking capabilities and borrow more from smaller banks, which are known to rely more on soft information in the credit granting process (Degryse and Ongena 2005). By influencing the nature of credit relationships between borrowers and lenders (i.e. arm's length vs. relational), trust may help determining which firms were more severely affected by the crisis depending on the banking structure in the area where they operate. It is possible, for instance, that during a crisis larger banks in high-trust areas favored non-family firms vis a vis the less transparent family counterpart. Together, these attributes may lead to a different interaction between trust and crisis 
on family firms' performance in regions with a higher presence of smaller banks. We use regionyear data from the Bank of Italy to define the ratio of the branches of small (minor and small) to large (major, large and average) banks in the region of firm's headquarter during our sample period. ${ }^{21}$ Columns (1)-(2) in Appendix Table A4 show the results for firms in regions with below- or above-median presence of small banks. We use the ratio of bank debt to total assets together with the usual firm controls and firm fixed effects. Results show that the negative interaction effect of trust and crisis on family firm performance has a similar magnitude in the two cases. Put it differently, there does not seem to be an heterogeneous effect of our result depending on bank size.

Using different trust cutoffs. So far we have classified high-trust using values above the median value. The results in Appendix Table A4 serve to alleviate potential concerns about the arbitrariness of this choice. In Column (3) we confirm our results redefining the high-trust indicator using values above the mean of 0.33 (approximately percentile 40). Since we find a result comparing to the bottom $40 \%$ of the sample, we next test whether there exists an incremental role of our high-trust indicator. Specifically, we split the below median category between a first 0.27 (percentile 25) and a second trust category (larger than 0.27 but smaller than 0.36, percentile 50) and keep a third, high trust category (above 0.36). Comparing to the omitted first category, Columns (4) and (5) show that there is indeed an incremental negative effect of trust for family firms. To avoid using subjective cutoffs, in Columns (6) and (7) we use a continuous measure of generalized trust and estimate results for the family and non-family firms samples, respectively. Our findings remain unchanged. Furthermore, these checks are robust to using the WVS data or the post-crisis trust from the European Social Survey wave from 2012.

\footnotetext{
${ }^{21}$ The Bank of Italy classifies banks into minor, small, average, large and major as a function of total deposits; this classification is revised every five years.
} 
Robustness to other aspects of social capital. Generalized trust may pick up the effect of other types of social capital in the area of the firm's headquarter. To address this concern, in Appendix Table A4 we check that our results do not change when adding the triple interaction between crisis, family firms and the regional average of the propensity to tolerate and respect other people (Column 8), and the number of non-sport daily newspapers sold by thousand people in region, which captures differences in accountability (Column 9) (see Nannicini et al. 2013 for details).

\section{Conclusion}

Economists have long noted that social trust matters for many outcomes spanning from political accountability (Nannicini et al. 2013) to crime (Buonanno et al. 2009). After a long silence on the topic, the literature is paying attention to the role of culture for markets and organizations (Roland 2020). This "cultural revolution", as Zingales (2015) calls it, opens up important avenues of research that broaden our understanding of corporate outcomes.

We expanded the literature on how culture shapes the real effect of financial crises (Stacchini and Degasperi 2015; Levine et al. 2018; Lins et al. 2017) by delving into the interaction between trust and ownership structures for trade financing and performance. Our results indicate that during the 2008-09 financial crisis, financing from suppliers was less readily available to family firms located in high-trust areas. Studying variations in corporate governance, we found that for family companies with non-family directors, trust does not alter the effect of the crisis on trade financing. Moving to performance, we found that, while the financial crisis had a negative effect on firm profitability, trust acts as a double-edged sword for determining the magnitude of such effect: for family firms, trust aggravates the negative effect of the financial 
crisis, whereas for non-family firms trust alleviates it. Similar to trade financing, trust exacerbates the negative effect of the crisis on performance only for those family firms with a high representation of family members in the board of directors.

Our findings expand the literature on the role of culture for organizational structures (Amore 2017; Bertrand and Schoar 2006; Bloom et al. 2012; La Porta et al. 1997). We underscore that cultural values in the area of the firm's headquarter work in conjunction with firm attributes in determining the effect of financial crises on company activities. Levine et al. (2018) argue that trust can provide firms with alternative financing channels during crises. Other studies show that trust facilitates trade financing when formal financing is limited (Allen et al. 2005; Wu et al. 2014). Our study sheds new light on the contextual advantages of different ownership forms during times of crisis.

\section{References}

Alesina, Alberto, Giuliano, Paola, 2015. Culture and institutions. Journal of Economic Literature 53, 889-915.

Allen, Franklin, Qian, Jun, Qian, Meijun, 2005. Law, finance, and economic growth in China. Journal of Financial Economics 77, 57-116.

Amit, Raphael, Ding, Yuan, Villalonga, Belén, Zhang, Hua, 2015. The role of institutional development in the prevalence and performance of entrepreneur and family-controlled firms. Journal of Corporate Finance 31, 284-305.

Amore, Mario Daniele, Bennedsen, Morten, 2013. The value of local political connections in a lowcorruption environment. Journal of Financial Economics 110, 387-402.

Amore, Mario Daniele, Garofalo, Orsola, Minichilli, Alessandro, 2014. Gender interactions within the family firm. Management Science 60, 1083-1097.

Amore, Mario Daniele, 2017. Social capital and family control. Explorations in Economic History 65, 106-114.

Anderson, Ronald C., Reeb, David M, 2003. Founding-family ownership, corporate diversification, and firm leverage. Journal of Law and Economics 46, 653-684. 
Anderson, Ronald C., Reeb, David M, 2004. Board composition: Balancing family influence in S\&P 500 firms. Administrative Science Quarterly 49, 209-237.

Anderson, Ronald C., Duru, Augustine, Reeb, David M, 2009. Founders, heirs, and corporate opacity in the United States. Journal of Financial Economics 92, 205-222.

Arrow, Kenneth J., 1972. Gifts and Exchanges. Philosophy \& Public Affairs 1, 343-362.

Bennedsen, Morten, Nielsen, Kasper M., Pérez-González, Francisco, Wolfenzon, Daniel, 2007. Inside the family firm: The role of families in succession decisions and performance. Quarterly Journal of Economics 118, 1169-1208.

Bertrand, Marianne, Schoar, Antoinette, 2006. The role of family in family firms. Journal of Economic Perspectives 20, 73-96.

Bloom, Nicholas, Van Reenen, John, 2007. Measuring and explaining management practices across firms and countries. Quarterly Journal of Economics 122, 1351-1408.

Bloom, Nicholas, Sadun, Raffaella, Van Reenen, John, 2012. The organization of firms across countries. Quarterly Journal of Economics 127, 1663-1705.

Bromiley, Philip, Cummings, Larry L, 1995. Transactions costs in organizations with trust. Research on Negotiation in Organizations 5, 219-250.

Bottazzi, Laura, Da Rin, Marco, Hellmann, Thomas F., 2016. The importance of trust for investment: Evidence from venture capital. Review of Financial Studies 29, 2283-2318.

Bunkanwanicha, Pramuan, Fan, Joseph P. H., Wiwattanakantang, Yupana, 2013. The value of marriage to family firms. Journal of Financial and Quantitative Analysis 48, 611-636.

Buonanno, Paolo, Montolio, Daniel, Vanin, Paolo, 2009. Does social capital reduce crime? Journal of Law and Economics 52, 145-170.

Burkart, Mike, Panunzi, Fausto, Shleifer, Andrei, 2003. Family firms. Journal of Finance 58, 21672201.

Campello, Murillo, Graham, John R., Harvey, Campbell R., 2010. The real effect of financial constraints: Evidence from a financial crisis. Journal of Financial Economics 97, 470-487.

Chami, Ralph, Fullenkamp, Conell, 2002. Trust and efficiency. Journal of Banking and Finance 26, 1785-1809.

Cingano, Federico, Pinotti, Paolo, 2016. Trust, firm organization, and the pattern of comparative advantage. Journal of International Economics 100, 1-13.

Cosset, Jean-Claude, Somé, Hyacinthe Y., Valery, Pascale, 2016. Does competition matter for corporate governance? The role of country characteristics. Journal of Financial and Quantitative Analysis 51, 1231-1267. 
Degryse, Hans, Ongena, Steven, 2005. Distance, lending relationships, and competition. Journal of Finance 60, 231-266.

Duchin, Ran, Ozbas, Oguzhan, Sensoy, Berk A., 2010. Costly external finance, corporate investment, and the subprime mortgage credit crisis. Journal of Financial Economics 97, 418-435.

Dyer, Jeffrey, Chu, Wujin, 2003. The role of trustworthiness in reducing transaction costs and improving performance: Empirical evidence from the United States, Japan and Korea. Organization Science 14, 57-68.

Faccio, Mara, Lang, Larry, 2002. The ultimate ownership of Western European corporations. Journal of Financial Economics 65, 365-395.

Garcia-Appendini, Emilia, Montoriol-Garriga, Judit, 2013. Firms as liquidity providers: Evidence from the 2007-2008 financial crisis. Journal of Financial Economics 109, 272-229.

Giorcelli, Michela, 2019. The long-term effects of management and technology transfers. American Economic Review 109, 1-33.

Guiso, Luigi, Sapienza, Paola, Zingales, Luigi, 2004. The role of social capital in financial development. American Economic Review 94, 526-556.

Guiso, Luigi, Sapienza, Paola, Zingales, Luigi, 2008. Trusting the stock market. Journal of Finance 63, 2557-2600.

Guiso, Luigi, Sapienza, Paola, Zingales, Luigi, 2009. Cultural biases in economic exchange. Quarterly Journal of Economics 124, 1095-1131.

Guiso, Luigi, Sapienza, Paola, Zingales, Luigi, 2011. Civic capital as the missing link. In Handbook of Social Economics 1, 417-480. Elsevier.

Guiso, Luigi, Sapienza, Paola, Zingales, Luigi, 2016. Long-term persistence. Journal of the European Economic Association 14, 1401-1436.

Gur, Nurullah, Bjornskov, Christian, 2017. Trust and delegation: Theory and evidence. Journal of Comparative Economics 45, 644-657.

Hilary, Gilles, Huang, Sterling, 2015. Trust and contracting. INSEAD Working Paper No. 2015/42/ACC.

Kahle, Kathleen M., Stulz, René, 2013. Access to capital, investment, and the financial crisis. Journal of Financial Economics 110, 280-299.

Knack, Stephen, Keefer, Philip, 1997. Does social capital have an economic payoff? A cross-country investigation. Quarterly Journal of Economics 112, 1251-1288.

La Porta, Rafael, Lopez-de-Silanes, Florencio, Shleifer, Andrei, Vishny Robert W., 1997. Trust in large organizations. American Economic Review 87, 333-338. 
Laeven, Luc, Valencia, Fabian, 2013. Systemic banking crises database. IMF Economic Review 61, 225-270.

Lagaras, Spyridon, Tsoutsoura, Margarita, 2015. Family control and the cost of debt: Evidence from the great recession. Chicago Booth Research Paper No. 15-14.

Levine, Ross, Lin, Chen, Xie, Wensi, 2018. Corporate resilience to banking crises: The role of trust and trade credit. Journal of Financial and Quantitative Analysis 53, 1441-1477.

Lins, Karl V., Volpin, Paolo, Wagner, Hannes F., 2013. Does family control matter? International evidence from the 2008-2009 financial crisis. Review of Financial Studies 26, 2583-2619.

Lins, Karl V., Servaes, Henri, Tamayo, Anne, 2017. Social capital, trust, and firm performance: The value of corporate social responsibility during the financial crisis. Journal of Finance 72, 1785 1824.

Miller, Danny, Minichilli, Alessandro, Corbetta, Guido, 2013. Is family leadership always beneficial? Strategic Management Journal 34, 553-571.

Miller, Danny, Le Breton-Miller, Isabelle, Amore, Mario Daniele, Minichilli, Alessandro, Corbetta, Guido, 2017. Institutional logics, family firm governance and performance. Journal of Business Venturing 32, 674-693.

Mueller, Holger M., Philippon, Thomas, 2011. Family firms and labor relations. American Economic Journal: Macroeconomics 3, 218-245.

Nannicini, Tomasso, Stella, Andrea, Tabellini, Guido, Troiano, Ugo, 2013. Social capital and political accountability. American Economic Journal: Economic Policy 5, 222-250.

Pérez-González, Francisco, 2006. Inherited control and firm performance. American Economic Review 96, 1559-1588.

Putnam, Robert D., 1993. Making Democracy Work. Civic Traditions in Modern Italy. Princeton University Press.

Roland, Gerard, 2020. The deep historical roots of modern culture: A comparative perspective. Journal of Comparative Economics, forthcoming.

Sangnier, Marc, 2013. Does trust favor macroeconomic stability? Journal of Comparative Economics 41, 653-668.

Sapienza, Paola, Zingales, Luigi, 2012. A trust crisis. International Review of Finance 12, 123-131.

Sapienza, Paola, Toldra-Simats, Anna, Zingales, Luigi, 2013. Understanding trust. Economic Journal $123,1313-1332$.

Stacchini, Massimiliano, Degasperi, Petra, 2015. Trust, family businesses and financial intermediation. Journal of Corporate Finance 33, 293-316. 
Tabellini, Guido, 2010. Culture and institutions: Economic development in the regions of Europe. Journal of the European Economic Association 8, 677-716.

Wu, Wenfeng, Firth, Michael, Rui, Oliver M., 2014. Trust and the provision of trade credit. Journal of Banking \& Finance 39, 146-159.

Zingales, Luigi, 2015. The "cultural revolution" in finance. Journal of Financial Economics 117, 1-4. 


\section{Figure 1. Differences in trust across Italian regions}

This figure illustrates the regional averages of the generalized trust measure from the World Value Survey. Darker shades represent higher values of generalized trust. The average (median) value is $0.33(0.36)$. When splitting the sample by the high-trust dummy, the averages are 0.28 and 0.37 for low and high-trust, respectively.

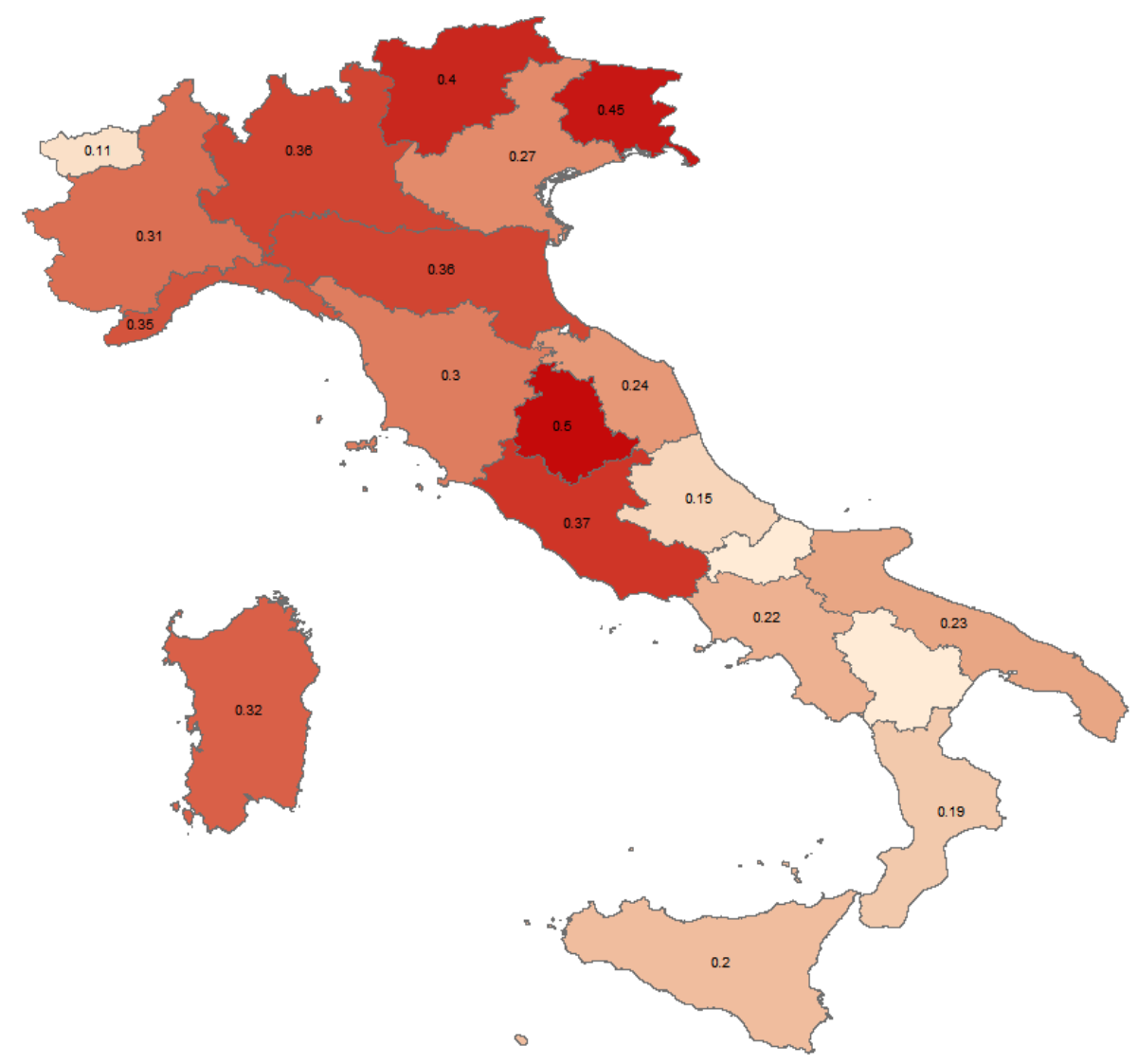


Figure 2. Average profitability in the pre-crisis years

These graphs illustrate the average ROA for family and non-family firms in high and low trust regions from the years 2000 to 2007.
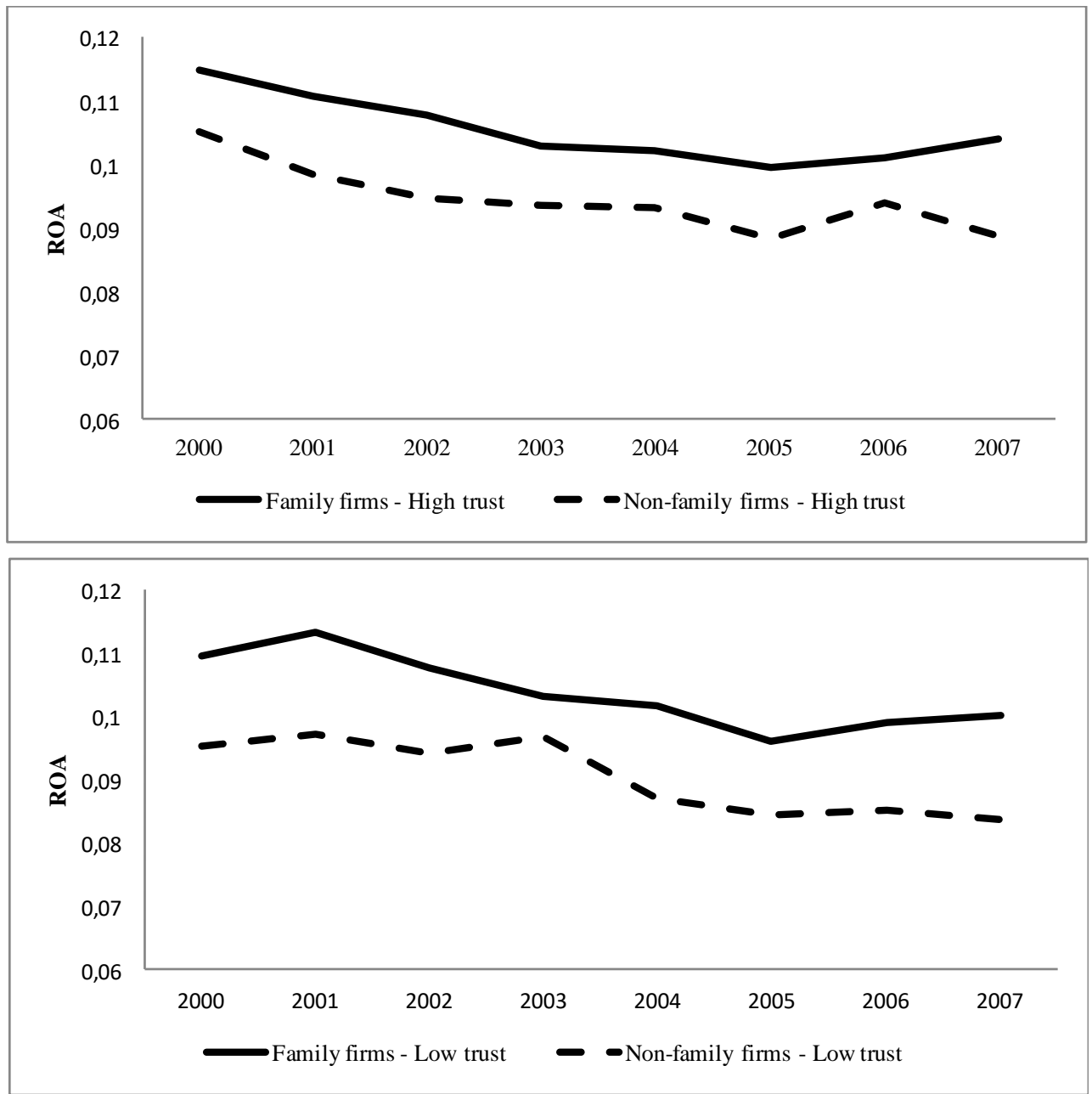
Figure 3. The effect of trust on family firm performance in pre- and post-crisis years

This graph illustrates the coefficients obtained from a regression in which the dependent variable is ROA, defined as the ratio of earnings before interest, taxes and depreciation to total assets, and the explanatory variables are the triple interaction between a set of dummies for each year in our sample period (using 2004 as reference year), the high-trust dummy and the family firm dummy, as well as the set of controls employed in Column (5) of Table 5. The crisis years are 2008-09. The regression includes firm fixed effects and clusters standard errors by firm. The solid line represents the regression coefficients for each of the year dummies interacted with high-trust and with the family firm dummy, together with the $95 \%$ confidence interval.

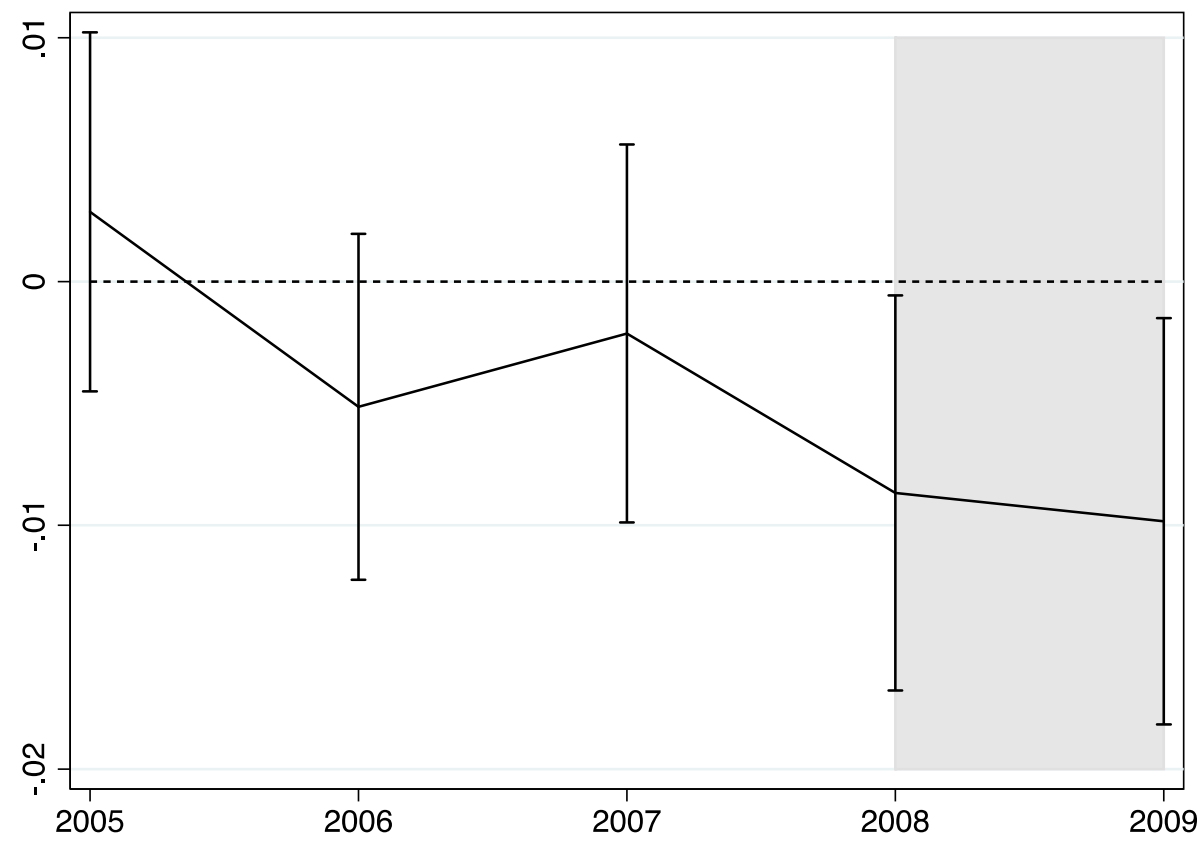




\section{Table 1. Descriptive statistics}

Trade financing is computed as accounts payable at the end of period $t$ minus accounts payable at the beginning of period $t$, divided by cost of goods sold during period $t$; for this variable, the sample is restricted to manufacturing firms only. ROA is defined as the ratio of earnings before interest, taxes and depreciation to total assets. Family firm is a dummy equal to one for family firms and zero otherwise. Trust average is the regional average of generalized trust from the World Value Survey. High-trust is a dummy variable equal to one if the region of a firm's headquarter is above the median trust value, and zero if the region of a firm's headquarter is below the median value. Ln(Total assets) is the logarithm of the firm's total assets. Cash holdings is the ratio of cash holdings and equivalents to total assets. Total debt is the ratio of total debt to total assets. Complete definitions are provided in Table A1.

\begin{tabular}{lclllll}
\hline Variable & Obs. & Mean & Std. dev. & Q1 & Median & Q3 \\
\hline Manufacturing firms & & & & & & \\
Trade financing & 18,788 & 0.004 & 0.068 & -0.030 & 0.004 & 0.037 \\
ROA & 18,788 & 0.102 & 0.089 & 0.053 & 0.088 & 0.138 \\
Family firm & 18,788 & 0.698 & 0.459 & 0.000 & 1.000 & 1.000 \\
Trust average & 18,788 & 0.327 & 0.063 & 0.268 & 0.357 & 0.362 \\
Ln(Total assets) & 18,788 & 10.526 & 1.153 & 9.785 & 10.384 & 11.159 \\
Cash holdings & 18,788 & 0.061 & 0.089 & 0.006 & 0.026 & 0.077 \\
Total debt & 18,788 & 0.615 & 0.197 & 0.484 & 0.639 & 0.768 \\
\hline Full sample & & & & & & \\
ROA & 71,605 & 0.091 & 0.098 & 0.044 & 0.079 & 0.127 \\
Family firm & 71,605 & 0.652 & 0.476 & 0.000 & 1.000 & 1.000 \\
Trust average & 71,605 & 0.328 & 0.063 & 0.298 & 0.357 & 0.362 \\
Ln(Total assets) & 71,605 & 10.346 & 1.535 & 9.464 & 10.249 & 11.183 \\
Cash holdings & 71,605 & 0.071 & 0.105 & 0.008 & 0.032 & 0.089 \\
Total debt & 71,605 & 0.658 & 0.210 & 0.524 & 0.694 & 0.821 \\
\hline
\end{tabular}




\section{Table 2. Effects of trust and financial crisis on trade financing}

The dependent variable is trade financing, computed as accounts payable at the end of period $t$ minus accounts payable at the beginning of period $t$, divided by cost of goods sold during period $t$. Crisis is a dummy equal to one for the crisis years of 2008-09 and zero for the years 2004-07. High-trust is a dummy variable equal to one if the region of a firm's headquarter is above the median trust value, and zero if the region of a firm's headquarter is below the median value. Family firm is a dummy equal to one for family firms and zero otherwise. Ln(Total assets) is the logarithm of the firm's total assets. Cash holdings is the ratio of cash holdings and equivalents to total assets. Total debt is the ratio of total debt to total assets. Columns (1)-(4) estimate the model for the subsamples of non-family and family firms separately, whereas Column (5) estimates the model on the full sample. Columns (6)-(7) split the sample between firms that have experienced an increase/no change (Column 6) or decrease (Column 7) in the average level of bank debt to total assets in the crisis period with respect to the pre-crisis period. Each model includes firm fixed effects. Because the trust dummy does not vary over time, it is perfectly collinear with the firm fixed effects and thus we exclude it from our estimation. This analysis is restricted to the subsample to manufacturing firms. $* \mathrm{p}<0.10$, $* * \mathrm{p}<0.05$, $* * * \mathrm{p}<0.01$. Firm-clustered standard errors are presented in parenthesis. Variables are summarized in Table 1 and complete definitions are provided in Table A1.

Dependent variable: Trade financing

Crisis

High-trust $\times$ Crisis

Ln(Total assets)

Long-term debt

ROA

Crisis $\times$ Family

High-trust $\times$ Crisis $\times$ Family

Constant

Firm fixed effects Observations

\begin{tabular}{|c|c|c|c|c|c|c|}
\hline $\begin{array}{l}\text { Non-family } \\
\text { (1) }\end{array}$ & $\begin{array}{l}\text { Family } \\
(2)\end{array}$ & $\begin{array}{l}\text { Non-family } \\
\text { (3) }\end{array}$ & $\begin{array}{l}\text { Family } \\
(4)\end{array}$ & $\begin{array}{l}\text { All } \\
(5)\end{array}$ & $\begin{array}{l}\text { Bank debt } \\
\text { decrease }=0 \\
(6)\end{array}$ & $\begin{array}{l}\text { Bank debt } \\
\text { decrease }=1 \\
(7)\end{array}$ \\
\hline$-0.036 * * *$ & $-0.042 * * *$ & $-0.035 * * *$ & $-0.043 * * *$ & $-0.036 * * *$ & $-0.041 * * *$ & $-0.033 * * *$ \\
\hline$(0.003)$ & $(0.002)$ & $(0.003)$ & $(0.002)$ & $(0.003)$ & $(0.004)$ & $(0.003)$ \\
\hline 0.003 & $-0.007 * * *$ & 0.004 & $-0.008 * * *$ & 0.004 & 0.004 & 0.005 \\
\hline$(0.004)$ & $(0.002)$ & $(0.004)$ & $(0.002)$ & $(0.004)$ & $(0.006)$ & $(0.005)$ \\
\hline $0.064 * * *$ & $0.063 * * *$ & $0.065 * * *$ & $0.066^{* * *}$ & $0.066 * * *$ & $0.076 * * *$ & $0.061 * * *$ \\
\hline \multirow[t]{9}{*}{$(0.007)$} & $(0.006)$ & $(0.007)$ & $(0.006)$ & $(0.005)$ & $(0.007)$ & $(0.007)$ \\
\hline & & $-0.066 * * *$ & $-0.139 * * *$ & $-0.108 * * *$ & $-0.134 * * *$ & $-0.079 * * *$ \\
\hline & & $(0.019)$ & $(0.015)$ & $(0.012)$ & $(0.016)$ & $(0.018)$ \\
\hline & & $0.057 * * *$ & $-0.034 * *$ & 0.006 & 0.022 & -0.009 \\
\hline & & $(0.019)$ & $(0.016)$ & $(0.013)$ & $(0.022)$ & $(0.015)$ \\
\hline & & & & $-0.006 * *$ & $-0.009 *$ & -0.003 \\
\hline & & & & $(0.003)$ & $(0.005)$ & $(0.004)$ \\
\hline & & & & $-0.011 * * *$ & -0.005 & $-0.015^{* * *}$ \\
\hline & & & & $(0.004)$ & $(0.007)$ & $(0.005)$ \\
\hline$-0.666^{* * *}$ & $-0.632 * * *$ & $-0.679 * * *$ & $-0.643 * * *$ & $-0.660 * * *$ & $-0.767 * * *$ & $-0.610 * * *$ \\
\hline$(0.072)$ & $(0.065)$ & $(0.073)$ & $(0.066)$ & $(0.051)$ & $(0.069)$ & $(0.072)$ \\
\hline Yes & Yes & Yes & Yes & Yes & Yes & Yes \\
\hline 5,680 & 13,108 & 5,680 & 13,108 & 18,788 & 7,965 & 10,627 \\
\hline
\end{tabular}




\section{Table 3. Heterogeneous effects on trade financing by governance characteristics}

The dependent variable is trade financing, computed as accounts payable at the end of period $t$ minus accounts payable at the beginning of period $t$, divided by cost of goods sold during period $t$. Crisis is a dummy equal to one for the crisis years of 2008-09 and zero for the years 2004-07. High-trust is a dummy variable equal to one if the region of a firm's headquarter is above the median trust value, and zero if the region of a firm's headquarter is below the median value. Each regression includes the firm-level controls of Table 2, as well as firm fixed effects. Because the trust dummy does not vary over time, it is perfectly collinear with the firm fixed effects and thus we exclude it from our estimation. In Column (1), the model is estimated on the subsample of family firms with only family members in the board of directors, whereas in Column (2) the model is estimated on the subsample of family firms with at least one non-family director. In Column (3), we estimate the model on the subsample of family firms with only family members as directors and CEOs, whereas in Column (4) we estimate the model on the subsample of family firms with any nonfamily director but a family CEO. This analysis is restricted to the subsample to manufacturing firms. $* \mathrm{p}<0.10, * *$ $\mathrm{p}<0.05, * * * \mathrm{p}<0.01$. Firm-clustered standard errors are presented in parenthesis. Main variables are summarized in Table 1 and complete definitions for all variables are provided in Table A1.

\begin{tabular}{lllll}
\hline Dependent variable: Trade financing & $\begin{array}{l}\text { Only family } \\
\text { directors }\end{array}$ & $\begin{array}{l}\text { Any non-family } \\
\text { director }\end{array}$ & $\begin{array}{l}\text { Only family } \\
\text { directors and } \\
\text { family CEO } \\
(3)\end{array}$ & $\begin{array}{l}\text { Any non-family } \\
\text { director and } \\
\text { family CEO } \\
(4)\end{array}$ \\
\cline { 2 - 5 } Crisis & $-0.037^{* * *}$ & $-0.037^{* * *}$ & $-0.037^{* * *}$ & $-0.037^{* * *}$ \\
High-trust $\times$ Crisis & $(0.003)$ & $(0.003)$ & $(0.003)$ & $(0.004)$ \\
& $-0.015 * * *$ & 0.000 & $-0.015 * * *$ & 0.001 \\
Constant & $(0.004)$ & $(0.004)$ & $(0.004)$ & $(0.005)$ \\
& $-0.940^{* * *}$ & $-0.852^{* * *}$ & $-0.939^{* * *}$ & $-0.911^{* * *}$ \\
Firm-level controls & $(0.119)$ & $(0.136)$ & $(0.119)$ & $(0.157)$ \\
Firm fixed effects & Yes & Yes & Yes & Yes \\
Observations & Yes & Yes & Yes & Yes \\
\hline
\end{tabular}




\section{Table 4. Heterogeneous effects on trade financing by industry}

The dependent variable is trade financing, computed as accounts payable at the end of period $t$ minus accounts payable at the beginning of period $t$, divided by cost of goods sold during period $t$. Crisis is a dummy equal to one for the crisis years of 2008-09 and zero for the years 2004-07. High-trust is a dummy variable equal to one if the region of a firm's headquarter is above the median trust value, and zero if the region of a firm's headquarter is below the median value. Each regression includes the firmlevel controls of Table 2, as well as firm fixed effects. Because the trust dummy does not vary over time, it is perfectly collinear with the firm fixed effects and thus we exclude it from our estimation. We take the median value of trade financing at the 2-digit manufacturing industry level to split the sample into firms with high (above the median) and low (below the median) industry reliance on trade financing. All models are estimated for the subsamples of non-family and family firms separately. Columns (1)-(2) estimate the model for firms with high industry reliance on trade financing, whereas Columns (3)-(4) estimate the model for firms with low industry reliance on trade financing. This analysis is restricted to the subsample to manufacturing firms. ${ }^{*} \mathrm{p}<0.10, * * \mathrm{p}<0.05, * * * \mathrm{p}<0.01$. Firmclustered standard errors are presented in parenthesis. Variables are summarized in Table 1 and complete definitions are provided in Table A1.

\begin{tabular}{lllll}
\hline Dependent variable: Trade financing & \multicolumn{2}{r}{$\begin{array}{r}\text { High industry reliance on } \\
\text { trade financing }\end{array}$} & \multicolumn{2}{c}{$\begin{array}{r}\text { Low industry reliance on } \\
\text { trade financing }\end{array}$} \\
& $\begin{array}{l}\text { Non-family } \\
(1)\end{array}$ & $\begin{array}{l}\text { Family } \\
(2)\end{array}$ & $\begin{array}{l}\text { Non-family } \\
(3)\end{array}$ & $\begin{array}{l}\text { Family } \\
(4)\end{array}$ \\
\cline { 2 - 5 } Crisis & $-0.041^{* * *}$ & $-0.047^{* * *}$ & $-0.027^{* * *}$ & $-0.037^{* * *}$ \\
& $(0.004)$ & $(0.002)$ & $(0.004)$ & $(0.002)$ \\
High-trust×Crisis & 0.004 & $-0.011^{* * *}$ & -0.000 & $-0.006^{*}$ \\
& $(0.005)$ & $(0.003)$ & $(0.005)$ & $(0.003)$ \\
Constant & $-0.731^{* * *}$ & $-0.714^{* * *}$ & $-0.643^{* * *}$ & $-0.576^{* * *}$ \\
& $(0.105)$ & $(0.086)$ & $(0.101)$ & $(0.098)$ \\
Firm-level controls & Yes & Yes & Yes & Yes \\
Firm fixed effects & Yes & Yes & Yes & Yes \\
Observations & 2,944 & 7,480 & 2,736 & 5,628 \\
\hline
\end{tabular}




\section{Table 5. Effects of trust and financial crisis on firm performance}

The dependent variable is ROA, computed as the ratio of earnings before interest, taxes and depreciation to total assets. Crisis is a dummy equal to one for the crisis years of 2008-09 and zero for the years 2004-07. High-trust is a dummy variable equal to one if the region of a firm's headquarter is above the median trust value, and zero if the region of a firm's headquarter is below the median value. Family firm is a dummy equal to one for family firms and zero otherwise. Ln(Total assets) is the logarithm of the firm's total assets. Cash holdings is the ratio of cash holdings and equivalents to total assets. Total debt is the ratio of total debt to total assets. Columns (1)-(2) and (3)-(4) estimate the model for the subsamples of non-family and family firms separately, whereas Column (5) estimates the model on the full sample. Each model includes firm fixed effects. Because the trust dummy does not vary over time, it is perfectly collinear with the firm fixed effects and thus we exclude it from our estimation. * $\mathrm{p}<0.10, * * \mathrm{p}<0.05, * * * \mathrm{p}<0.01$. Firm-clustered standard errors are presented in parenthesis. Variables are summarized in Table 1 and complete definitions are provided in Table A1.

\begin{tabular}{|c|c|c|c|c|c|}
\hline \multicolumn{6}{|l|}{ Dependent variable: ROA } \\
\hline & $\begin{array}{l}\text { Non-family } \\
\text { (1) }\end{array}$ & $\begin{array}{l}\text { Family } \\
\text { (2) }\end{array}$ & $\begin{array}{l}\text { Non-family } \\
\text { (3) }\end{array}$ & $\begin{array}{l}\text { Family } \\
\text { (4) }\end{array}$ & $\begin{array}{l}\text { All } \\
(5)\end{array}$ \\
\hline Crisis & $\begin{array}{l}-0.013 * * * \\
(0.002)\end{array}$ & $\begin{array}{l}-0.014 * * * \\
(0.001)\end{array}$ & $\begin{array}{l}-0.017 * * * \\
(0.002)\end{array}$ & $\begin{array}{l}-0.020 * * * \\
(0.001)\end{array}$ & $\begin{array}{l}-0.016 * * * \\
(0.002)\end{array}$ \\
\hline High-trust $\times$ Crisis & $\begin{array}{l}0.004 * \\
(0.002)\end{array}$ & $\begin{array}{l}-0.003 * * \\
(0.001)\end{array}$ & $\begin{array}{l}0.004 * \\
(0.002)\end{array}$ & $\begin{array}{l}-0.003^{* *} \\
(0.001)\end{array}$ & $\begin{array}{l}0.004 * \\
(0.002)\end{array}$ \\
\hline Ln(Total assets) & $\begin{array}{l}0.017 * * * \\
(0.003)\end{array}$ & $\begin{array}{l}0.013 * * * \\
(0.002)\end{array}$ & $\begin{array}{l}0.025 * * * \\
(0.004)\end{array}$ & $\begin{array}{l}0.020 \text { *** } \\
(0.002)\end{array}$ & $\begin{array}{l}0.022 * * * \\
(0.002)\end{array}$ \\
\hline Cash holdings & & & $\begin{array}{l}0.011 \\
(0.016)\end{array}$ & $\begin{array}{l}0.038 * * * \\
(0.015)\end{array}$ & $\begin{array}{l}0.027 * * \\
(0.011)\end{array}$ \\
\hline Total debt & & & $\begin{array}{l}-0.138^{* * *} \\
(0.014)\end{array}$ & $\begin{array}{l}-0.108^{* * *} \\
(0.013)\end{array}$ & $\begin{array}{l}-0.121 \text { *** } \\
(0.009)\end{array}$ \\
\hline Crisis $\times$ Family & & & & & $\begin{array}{l}-0.005 * * \\
(0.002)\end{array}$ \\
\hline High-trust $\times$ Crisis $\times$ Family & & & & & $\begin{array}{l}-0.008 * * * \\
(0.003)\end{array}$ \\
\hline Constant & $\begin{array}{l}-0.088^{* *} \\
(0.036)\end{array}$ & $\begin{array}{l}-0.032 \\
(0.022)\end{array}$ & $\begin{array}{l}-0.084 * * \\
(0.037)\end{array}$ & $\begin{array}{l}-0.036^{*} \\
(0.022)\end{array}$ & $\begin{array}{l}-0.055^{* * *} \\
(0.020)\end{array}$ \\
\hline Firm fixed effects & Yes & Yes & Yes & Yes & Yes \\
\hline Observations & 24,900 & 46,705 & 24,900 & 46,705 & 71,605 \\
\hline
\end{tabular}




\section{Table 6. Heterogeneous effects on firm performance by governance characteristics}

The dependent variable is ROA, computed as the ratio of earnings before interest, taxes and depreciation to total assets. Crisis is a dummy equal to one for the crisis years of 2008-09 and zero for the years 2004-07. High-trust is a dummy variable equal to one if the region of a firm's headquarter is above the median trust value, and zero if the region of a firm's headquarter is below the median value. Each regression includes the firm-level controls of Table 5, Column (5) as well as firm fixed effects. Because the trust dummy does not vary over time, it is perfectly collinear with the firm fixed effects and thus we exclude it from our estimation. In Column (1), the model is estimated on the subsample of family firms with only family members in the board of directors, whereas in Column (2) the model is estimated on the subsample of family firms with at least one non-family director. In Column (3), we estimate the model on the subsample of family firms with only family members as directors and CEOs, whereas in Column (4) we estimate the model on the subsample of family firms with any non-family director but a family CEO. $* \mathrm{p}<0.10, * *$ $\mathrm{p}<0.05, * * * \mathrm{p}<0.01$. Firm-clustered standard errors are presented in parenthesis. Main variables are summarized in Table 1 and complete definitions for all variables are provided in Table A1.

\begin{tabular}{lllll}
\hline Dependent variable: ROA & $\begin{array}{l}\text { Only family } \\
\text { directors }\end{array}$ & $\begin{array}{l}\text { Any non-family } \\
\text { director }\end{array}$ & $\begin{array}{l}\text { Only family } \\
\text { directors and } \\
\text { family CEO } \\
(3)\end{array}$ & $\begin{array}{l}\text { Any non-family } \\
\text { director and } \\
\text { family CEO } \\
(4)\end{array}$ \\
\cline { 2 - 5 } Crisis & $-0.018^{* * *}$ & $-0.018^{* * *}$ & $-0.018^{* * *}$ & $-0.020^{* * *}$ \\
High-trust×Crisis & $(0.002)$ & $(0.003)$ & $(0.002)$ & $(0.002)$ \\
Constant & $-0.005^{*}$ & -0.003 & $-0.005^{*}$ & -0.001 \\
& $(0.003)$ & $(0.002)$ & $(0.003)$ & $(0.003)$ \\
Firm-level controls & -0.023 & -0.016 & -0.024 & -0.038 \\
Firm fixed effects & $(0.045)$ & $(0.055)$ & $(0.045)$ & $(0.059)$ \\
Observations & Yes & Yes & Yes & Yes \\
\hline
\end{tabular}




\section{Table 7. The 1952-58 Productivity Program and family ownership}

This table presents results from a linear probability model in which the dependent variable is the family firm dummy and the main explanatory variable is the indicator equal to one if the province of the firm's headquarter is one of the experimental provinces of the Productivity Program (19521958) and zero for nonexperimental provinces in the pilot regions. The sample includes manufacturing firms founded before 1951. Column (2) includes the controls of Table 5, Column (5). * p<0.10, ** $\mathrm{p}<0.05$, *** $\mathrm{p}<0.01$. Robust standard errors are presented in parenthesis. Main variables are summarized in Table 1 and complete definitions for all variables are provided in Table A1.

Dependent variable: Family firm

\begin{tabular}{lll} 
& $(1)$ & $(2)$ \\
\cline { 2 - 3 } Experimental province & $-0.158^{* *}$ & $-0.141^{*}$ \\
& $(0.075)$ & $(0.074)$ \\
Firm-level controls & & Yes \\
Observations & 1,608 & 1,608 \\
\hline
\end{tabular}




\section{Table 8. 2SLS results}

This table presents, in Column (2), the results obtained estimating a 2 SLS in which the family firm dummy is instrumented with the indicator equal to one if the province of the firm's headquarter is one of the experimental provinces of the Productivity Program (1952-1958) and zero for nonexperimental provinces in the pilot regions. The sample includes manufacturing firms founded before 1951. For comparison purposes, Column (1) reports results from our baseline specification estimated using this small sample. Each model includes the controls of Table 5, Column (5) and firm fixed effects. Because the trust dummy does not vary over time, it is perfectly collinear with the firm fixed effects and thus we exclude it from our estimation. $* \mathrm{p}<0.10, * * \mathrm{p}<0.05, * * * \mathrm{p}<0.01$. Robust standard errors are presented in parenthesis. Main variables are summarized in Table 1 and complete definitions for all variables are provided in Table A1.

\begin{tabular}{lll}
\hline Dependent variable: ROA & & \\
& OLS & 2 SLS \\
& $(1)$ & $(2)$ \\
\cline { 2 - 3 } Crisis & $-0.028^{* * *}$ & -0.033 \\
& $(0.008)$ & $(0.021)$ \\
High-trust×Crisis & $0.028^{* * *}$ & $0.044^{*}$ \\
& $(0.010)$ & $(0.024)$ \\
Crisis $\times$ Family & 0.011 & 0.019 \\
& $(0.010)$ & $(0.034)$ \\
High-trust $\times$ Crisis $\times$ Family & $-0.038^{* * *}$ & $-0.066^{*}$ \\
& $(0.012)$ & $(0.040)$ \\
Constant & $0.142^{* *}$ & $0.173^{* * *}$ \\
& $(0.066)$ & $(0.061)$ \\
Firm-level controls & Yes & Yes \\
Firm fixed effects & Yes & Yes \\
Observations & 1,608 & 1,608 \\
\hline
\end{tabular}




\section{Appendix}

\section{Table A1. Definitions of variables}

\section{Variable \\ Generalized trust}

High-trust

Post-crisis trust

\section{Financial crisis}

Crisis

\section{Accounting variables}

Trade financing

ROA

Ln(Total assets)

Cash holdings

Total debt

Long term debt

Bank debt

TFP

ROS

Revenue-to-assets

Governance variables Family firm

Family board members

\section{Definition}

Constructed using the regional-level percentage of respondents to the World Values Survey (WVS, 2005 wave) who indicate that "most people can be trusted" when asked "Generally speaking, would you say that most people can be trusted, or that you can't be too careful in dealing with people?". We then take the median split of this variable to define the dummy High-trust, which takes the value of one for regions with high-trust, and zero otherwise.

Trust measure constructed using the European Social Survey (2012 wave). The variable is defined in the same way as the high-trust variable and is based on a survey question identical to the WVS.

Dummy variable equal to one during the three core years of the financial crisis in Italy (2008-09), and zero otherwise (2004-07).

Accounts payable at the end of period $t$ minus accounts payable at the beginning of period $t$, divided by cost of goods sold during period $t$. Observations are trimmed at the $1 \%$ level in the right and left tails of the distribution.

Return on assets defined as earnings before interest, taxes and depreciation (EBITDA) / Total assets.

The natural logarithm of the firm's book value of total assets.

Cash flow and equivalents / Total assets (negative values and values greater than one are set to 0 and 1 , respectively).

Total debt / Total assets (negative values and values greater than one are set to 0 and 1 , respectively).

Long term debt / Total assets (negative values and values greater than one are set to 0 and 1 , respectively).

Bank debt / Total assets (negative values and values greater than one are set to 0 and 1 , respectively).

Total factor productivity computed as the residuals from regressing the natural logarithm of revenues on the natural logarithm of employees, the natural logarithm of the value of fixed assets, and year and 2-digit industry dummies.

Return on sales defined as Net Profit / Revenues

The natural logarithm of the ratio of the firm's revenues to total assets.

A dummy variable equal to one if the firm is a family firm and zero otherwise. We classify a company as family-controlled if at least $50 \%$ of its equity shares is in the hands of a family (or $25 \%$ if the company is listed).

The share of family board members in the total number of board members. We create a dummy variable that takes the value of one if the share of family board members is one, and zero otherwise. Family membership of board members is defined using surname affinity with the controlling family. To avoid 
Family CEO

misclassification of spouses, the data sources adopt a cohabitation criterion which classifies as family members individuals of opposite gender living in the same personal address of the main family owner.

A dummy variable that takes the value of one if the firm has a family CEO and zero otherwise. Family CEOs are identified in the same way as family board members.

\section{Region, province and industry characteristics}

Experimental province

GDP growth

Employment

Length of judiciary trials

Corruption

Net firm entry

Firms per 1000 people

Employees per firm

Industry HHI

Exposure to small banks

in region

Tolerance

Daily newspaper
Dummy equal to one if the province in a given pilot region of the US Productivity Program of firm headquarter was covered by the program, and zero for provinces in pilot regions not covered by the program (from Giorcelli 2019).

Annual regional GDP growth (from the ISTAT, Italian National Statistics Office). Annual regional employment rate (from ISTAT).

Regional level length of judiciary trials (from ISTAT).

Annual regional level of corruption (from ISTAT).

The regional-level difference between the ratio of entry rate minus the ratio of firms' mortality rate within 5 years (from ISTAT).

Annual regional ratio of firms per thousand inhabitants (from ISTAT).

Annual regional number of employees per firm (from ISTAT).

Herfindahl-Hirschman Index computed at the 2-digit industry level as the annual sum of the firms' squared market shares (firm revenues divided by total revenues in industry).

The ratio of the branches of smaller (minor and small) to larger (major, large and average) banks in the region. Data from the Bank of Italy, which classifies banks as a function of total deposits, and revises the classification every five years.

Regional average of the propensity to tolerate and respect other people (as in Nannicini et al. 2013).

The number of non-sport daily newspapers sold by thousand people in region (as in Nannicini et al. 2013). 
Table A2. Trust vs. macroeconomic, institutional and industry characteristics

The dependent variable is ROA, computed as the ratio of earnings before interest, taxes and depreciation to total assets. Crisis is a dummy equal to one for the crisis years of 2008-09 and zero for the years 2004-07. High-trust is a dummy variable equal to one if the region of a firm's headquarter is above the median trust value, and zero if the region of a firm's headquarter is below the median value. Family firm is a dummy equal to one for family firms and zero otherwise. Unless differently specified, each model includes the controls of Table 5, Column (5) and firm fixed effects. Because the trust dummy does not vary over time, it is perfectly collinear with the firm fixed effects and thus we exclude it from our estimation. In Column (1), we control for the triple interactions between crisis, family and dummies for north-east, north-west, center and south of Italy. In Column (2) we and the triple interactions between the crisis and family dummies and regional GDP growth, and in Column (3) we also add the triple interactions with regional employment rates from ISTAT (Italian National Statistics Office). In Columns (3) and (4) we add the triple interactions between the regional length of judiciary trials and the regional level of corruption from ISTAT. Column (5) introduces all controls from Columns (2) to (4) together. Columns (6) to (9) maintain the GDP growth and judiciary trials triple interactions and add: the triple interaction between HHI, crisis and high-trust (Column 6); the triple interactions between crisis, high-trust and the ratio of firms per thousand inhabitants, the number of employees per firm, and a ratio of net firm entry computed as the difference between the ratio of entry rate minus the ratio of firms' mortality rate within 5 years (data from ISTAT) (Column 7); and interactions between 2-digit industry dummies and crisis dummy (Column 8). * p<0.10, ** p<0.05, *** $\mathrm{p}<0.01$. Firm-clustered standard errors are presented in parenthesis. Main variables are summarized in Table 1 and complete variable definitions are provided in Table A1.

\begin{tabular}{|c|c|c|c|c|c|c|c|c|}
\hline \multicolumn{9}{|l|}{ Dependent variable: ROA } \\
\hline & (1) & (2) & (3) & (4) & $(5)$ & $(6)$ & (7) & (8) \\
\hline \multirow[t]{2}{*}{ Crisis } & $-0.019 * * *$ & $-0.022 * * *$ & 0.021 & 0.012 & 0.020 & $-0.033 * * *$ & 0.006 & $-0.026 * * *$ \\
\hline & $(0.002)$ & $(0.003)$ & $(0.014)$ & $(0.024)$ & $(0.024)$ & $(0.006)$ & $(0.026)$ & $(0.007)$ \\
\hline \multirow[t]{2}{*}{ High-trust $\times$ Crisis } & $0.006^{* *}$ & 0.002 & 0.002 & 0.002 & 0.001 & -0.002 & 0.018 & -0.000 \\
\hline & $(0.003)$ & $(0.003)$ & $(0.003)$ & $(0.003)$ & $(0.003)$ & $(0.003)$ & $(0.041)$ & $(0.003)$ \\
\hline \multirow[t]{2}{*}{ Crisis $\times$ Family } & $-0.005 * *$ & -0.003 & -0.004 & -0.008 & -0.018 & -0.007 & -0.010 & -0.001 \\
\hline & $(0.003)$ & $(0.003)$ & $(0.015)$ & $(0.027)$ & $(0.027)$ & $(0.007)$ & $(0.007)$ & $(0.007)$ \\
\hline \multirow[t]{2}{*}{ High-trust $\times$ Crisis $\times$ Family } & $-0.007 * *$ & $-0.008 * * *$ & $-0.007 * *$ & $-0.007 * *$ & $-0.006^{* *}$ & $-0.007 * *$ & $-0.007 * *$ & $-0.006^{*}$ \\
\hline & $(0.003)$ & $(0.003)$ & $(0.003)$ & $(0.003)$ & $(0.003)$ & $(0.003)$ & $(0.003)$ & $(0.003)$ \\
\hline \multirow[t]{2}{*}{ Constant } & -0.025 & $-0.058 * * *$ & $-0.069 * *$ & $-0.071 * *$ & $-0.099 *$ & $-0.056^{* * *}$ & $-0.405 * * *$ & $-0.051 * *$ \\
\hline & $(0.022)$ & $(0.020)$ & $(0.034)$ & $(0.034)$ & $(0.052)$ & $(0.020)$ & $(0.042)$ & $(0.020)$ \\
\hline Area $\times$ Crisis $\times$ Family interactions & Yes & & & & & & & \\
\hline GDP growth $\times$ Crisis $\times$ Family interactions & & Yes & Yes & Yes & Yes & Yes & Yes & Yes \\
\hline Employment $\times$ Crisis $\times$ Family interactions & & & Yes & Yes & Yes & & & \\
\hline Length of judiciary trials $\times$ Crisis $\times$ Family interactions & & & & Yes & Yes & Yes & Yes & Yes \\
\hline Corruption $\times$ Crisis $\times$ Family interactions & & & & & Yes & & & \\
\hline Industry $\mathrm{HHI} \times$ Crisis $\times$ High-trust interactions & & & & & & Yes & & \\
\hline Net firm entry $\times$ Crisis $\times$ High-trust interactions & & & & & & & Yes & \\
\hline Firms per 1000 people $\times$ Crisis $\times$ High-trust interactions & & & & & & & Yes & \\
\hline Employees per firm $\times$ Crisis $\times$ High-trust interactions & & & & & & & Yes & \\
\hline Industry dummies $\times$ Crisis & & & & & & & & Yes \\
\hline Firm-level controls & Yes & Yes & Yes & Yes & Yes & Yes & Yes & Yes \\
\hline Firm fixed effects & Yes & Yes & Yes & Yes & Yes & Yes & Yes & Yes \\
\hline Observations & 71,605 & 71,605 & 71,605 & 71,430 & 49,676 & 71,293 & 71,430 & 71,429 \\
\hline
\end{tabular}




\section{Table A3. Robustness checks}

Unless differently specified, the dependent variable is ROA, computed as the ratio of earnings before interest, taxes and depreciation to total assets. Crisis is a dummy equal to one for the crisis years of 2008-09 and zero for the years 2004-07. High-trust is a dummy variable equal to one if the region of a firm's headquarter is above the median trust value, and zero if the region of a firm's headquarter is below the median value. Family firm is a dummy equal to one for family firms and zero otherwise. Unless differently specified, each model includes the controls of Table 5, Column (5) and firm fixed effects. Because the trust dummy does not vary over time, it is perfectly collinear with the firm fixed effects and thus we exclude it from our estimation. In Column (1), we replace our baseline trust variable with a randomly assigned value of regional trust to our sample firms. In Column (2) we employ data from the European Social Survey and replace our baseline trust variable (measured using the pre-crisis year of 2005) with a measure of generalized trust in 2012. In Column (3), the dependent variable is a firm's total factor productivity (TFP) computed as the residuals from regressing the natural logarithm of revenues on the natural logarithm of employees, the natural logarithm of the value of fixed assets, year and industry dummies. In Column (4), we use the return on sales (ROS) defined as firm profit divided by total revenues. In Column (5), the dependent variable is the logarithm of the ratio of a firm's revenues to total assets. In Column (6), we cluster standard errors at region level. In Column (7) we interact we interact firm age and our controls for firm size, cash holdings and debt level with the crisis and high-trust dummies. In Column (8) we remove from the analysis observations associated with family firms that change the fraction of family equity capital over time. All results are robust to including the full set of triple interactions between crisis and family firm dummies and regional economic and institutional quality measures. $* \mathrm{p}<0.10, * * \mathrm{p}<0.05, * * * \mathrm{p}<0.01$. Unless differently specified, firm-clustered standard errors are presented in parenthesis. Main variables are summarized in Table 1 and complete definitions for all variables are provided in Table A1.

\begin{tabular}{|c|c|c|c|c|c|c|c|c|}
\hline Robustness check: & $\begin{array}{l}\text { Placebo } \\
\text { trust }\end{array}$ & $\begin{array}{l}\text { Post-crisis } \\
\text { trust }\end{array}$ & $\begin{array}{l}\text { TFP as } \\
\text { dependent } \\
\text { variable }\end{array}$ & $\begin{array}{l}\text { ROS as } \\
\text { dependent } \\
\text { variable }\end{array}$ & $\begin{array}{l}\text { Revenues- } \\
\text { to-assets } \\
\text { as } \\
\text { dependent } \\
\text { variable }\end{array}$ & $\begin{array}{l}\text { Region } \\
\text { clustered } \\
\text { s.e. }\end{array}$ & $\begin{array}{l}\text { Age and } \\
\text { firm } \\
\text { controls } \times \\
\text { Crisis } \times \\
\text { High-trust }\end{array}$ & $\begin{array}{l}\text { Stable } \\
\text { equity }\end{array}$ \\
\hline & (1) & (2) & (3) & (4) & $(5)$ & (6) & (7) & (8) \\
\hline Crisis & $\begin{array}{l}-0.013 * * * \\
(0.002)\end{array}$ & $\begin{array}{l}-0.015 * * * \\
(0.002)\end{array}$ & $\begin{array}{l}-0.011 \\
(0.010)\end{array}$ & $\begin{array}{l}-0.008 * * * \\
(0.001)\end{array}$ & $\begin{array}{l}0.035^{* * * *} \\
(0.010)\end{array}$ & $\begin{array}{l}-0.016 * * * \\
(0.002)\end{array}$ & $\begin{array}{l}-0.044 * * \\
(0.019)\end{array}$ & $\begin{array}{l}-0.016 * * * \\
(0.002)\end{array}$ \\
\hline High-trust $\times$ Crisis & $\begin{array}{l}-0.001 \\
(0.002)\end{array}$ & $\begin{array}{l}0.002 \\
(0.002)\end{array}$ & $\begin{array}{l}0.023^{*} \\
(0.013)\end{array}$ & $\begin{array}{l}0.001 \\
(0.001)\end{array}$ & $\begin{array}{l}0.035^{* *} \\
(0.014)\end{array}$ & $\begin{array}{l}0.004 * * \\
(0.002)\end{array}$ & $\begin{array}{l}0.011 \\
(0.022)\end{array}$ & $\begin{array}{l}0.004 * \\
(0.002)\end{array}$ \\
\hline Crisis $\times$ Family & $\begin{array}{l}-0.010 * * * \\
(0.002)\end{array}$ & $\begin{array}{l}-0.005^{* *} \\
(0.002)\end{array}$ & $\begin{array}{l}-0.056^{* * *} * \\
(0.011)\end{array}$ & $\begin{array}{l}-0.002 * \\
(0.001)\end{array}$ & $\begin{array}{l}-0.058 * * * \\
(0.011)\end{array}$ & $\begin{array}{l}-0.005 * * * \\
(0.002)\end{array}$ & $\begin{array}{l}-0.006 * * * \\
(0.002)\end{array}$ & $\begin{array}{l}-0.005 * * \\
(0.002)\end{array}$ \\
\hline High-trust $\times$ Crisis $\times$ Family & $\begin{array}{l}0.002 \\
(0.003)\end{array}$ & $\begin{array}{l}-0.007 * * \\
(0.003)\end{array}$ & $\begin{array}{l}-0.038^{* *} \\
(0.015)\end{array}$ & $\begin{array}{l}-0.004 * * \\
(0.002)\end{array}$ & $\begin{array}{l}-0.053 * * * \\
(0.017)\end{array}$ & $\begin{array}{l}-0.008 * * \\
(0.004)\end{array}$ & $\begin{array}{l}-0.009 * * * \\
(0.003)\end{array}$ & $\begin{array}{l}-0.008 * * * \\
(0.003)\end{array}$ \\
\hline Constant & $\begin{array}{l}-0.055^{* * *} \\
(0.020)\end{array}$ & $\begin{array}{l}-0.055^{* * * *} \\
(0.020)\end{array}$ & $\begin{array}{l}-3.835^{* * * *} \\
(0.192)\end{array}$ & $\begin{array}{l}-0.046^{* * * *} \\
(0.009)\end{array}$ & $\begin{array}{l}0.490 * * * \\
(0.159)\end{array}$ & $\begin{array}{l}-0.055^{* * *} * \\
(0.016)\end{array}$ & $\begin{array}{l}-0.032 * \\
(0.019)\end{array}$ & $\begin{array}{l}-0.055^{* * *} * \\
(0.020)\end{array}$ \\
\hline Firm-level controls & Yes & Yes & Yes & Yes & Yes & Yes & Yes & Yes \\
\hline Firm fixed effects & Yes & Yes & Yes & Yes & Yes & Yes & Yes & Yes \\
\hline Observations & 71,605 & 71,406 & 64,095 & 69,325 & 70,799 & 71,605 & 71,596 & 67,569 \\
\hline
\end{tabular}




\section{Table A4. Exposure to bank types, alternative trust cutoffs and social capital}

The dependent variable is ROA, computed as the ratio of earnings before interest, taxes and depreciation to total assets. Crisis is a dummy equal to one for the crisis years of 2008-09 and zero for the years 2004-07. High-trust is a dummy variable equal to one if the region of a firm's headquarter is above the median trust value, and zero if the region of a firm's headquarter is below the median value. Family firm is a dummy equal to one for family firms and zero otherwise. Each model includes the controls of Table 5, Column (5) and firm fixed effects. Because the trust dummy does not vary over time, it is perfectly collinear with the firm fixed effects and thus we exclude it from our estimation. In Columns (1) and (2), we split the sample between firms with a low (Column 1) and high (Column 2) exposure to small banks in the region of firm headquarter. In Column (3) we redefine the high-trust indicator by taking a mean (0.33 trust level) instead of median split (0.36). In Columns (4) and (5) we create three categories on the distribution of trust (cutting at trust levels of 0.27 and 0.36 ). and interact them (omitting the bottom category) with the crisis dummy on the family and nonfamily subsamples, respectively. In columns (6) and (7) we use the continuous measure of trust on the family and non-family samples, respectively. In columns (8) and (9) we control for the triple interaction between crisis, family firms and: the regional average of the propensity to tolerate and respect other people (retrieved from WVS) (Column 8), and the number of non-sport daily newspapers sold by thousand people in region (Column 9 ). $* \mathrm{p}<0.10, * * \mathrm{p}<0.05$, $* * * \mathrm{p}<0.01$. Firm-clustered standard errors are presented in parenthesis. Variables are summarized in Table 1 and complete definitions are provided in Table A1.

\begin{tabular}{|c|c|c|c|c|c|c|c|c|c|}
\hline \multicolumn{10}{|l|}{ Dependent variable: ROA } \\
\hline Robustness check: & $\begin{array}{l}\text { Low } \\
\text { exposure to } \\
\text { small banks } \\
\text { (1) }\end{array}$ & $\begin{array}{l}\text { High } \\
\text { exposure to } \\
\text { small banks } \\
\text { (2) }\end{array}$ & $\begin{array}{l}\text { High-trust by } \\
\text { mean split } \\
\text { (3) }\end{array}$ & $\begin{array}{l}\text { 3-category } \\
\text { Trust } \\
\text { Family } \\
\text { Firms } \\
(4)\end{array}$ & $\begin{array}{l}\text { 3-category } \\
\text { Trust Non- } \\
\text { Family } \\
\text { Firms } \\
\text { (5) }\end{array}$ & $\begin{array}{l}\text { Continuous } \\
\text { Trust } \\
\text { Family } \\
\text { Firms } \\
(6)\end{array}$ & $\begin{array}{l}\text { Continuous } \\
\text { Trust Non- } \\
\text { Family } \\
\text { Firms } \\
(7)\end{array}$ & $\begin{array}{l}\text { Tolerance } \\
\times \text { Crisis } \times \\
\text { Family } \\
\text { Firm } \\
(8)\end{array}$ & $\begin{array}{l}\text { Daily } \\
\text { newspaper } \\
\times \text { Crisis } \times \\
\text { Family Firm } \\
(9)\end{array}$ \\
\hline Crisis & $\begin{array}{l}-0.012 * * \\
(0.005)\end{array}$ & $\begin{array}{l}-0.015 * * * \\
(0.002)\end{array}$ & $\begin{array}{l}-0.015 * * * \\
(0.002)\end{array}$ & $\begin{array}{l}-0.018 * * * \\
(0.002)\end{array}$ & $\begin{array}{l}-0.015^{* * * *} \\
(0.003)\end{array}$ & $\begin{array}{l}-0.008 * * \\
(0.004)\end{array}$ & $\begin{array}{l}-0.011 \\
(0.008)\end{array}$ & $\begin{array}{l}0.004 \\
(0.017)\end{array}$ & $\begin{array}{l}-0.013 * * * \\
(0.005)\end{array}$ \\
\hline High-trust $\times$ Crisis & $\begin{array}{l}-0.000 \\
(0.005)\end{array}$ & $\begin{array}{l}0.005 \\
(0.005)\end{array}$ & $\begin{array}{l}0.002 \\
(0.003)\end{array}$ & & & $\begin{array}{l}-0.040 * * * \\
(0.011)\end{array}$ & $\begin{array}{l}-0.010 \\
(0.022)\end{array}$ & $\begin{array}{l}0.003 \\
(0.003)\end{array}$ & $\begin{array}{l}0.004 * \\
(0.002)\end{array}$ \\
\hline Crisis $\times$ Family & $\begin{array}{l}-0.000 \\
(0.005)\end{array}$ & $\begin{array}{l}-0.005 * \\
(0.002)\end{array}$ & $\begin{array}{l}-0.005^{*} \\
(0.002)\end{array}$ & & & & & $\begin{array}{l}-0.032 * \\
(0.018)\end{array}$ & $\begin{array}{l}-0.005 \\
(0.005)\end{array}$ \\
\hline High-trust $\times$ Crisis $\times$ Family & $\begin{array}{l}-0.014 * * \\
(0.006)\end{array}$ & $\begin{array}{l}-0.011 * \\
(0.006)\end{array}$ & $\begin{array}{l}-0.007 * * \\
(0.003)\end{array}$ & & & & & $\begin{array}{l}-0.006 * \\
(0.003)\end{array}$ & $\begin{array}{l}-0.007 * * \\
(0.003)\end{array}$ \\
\hline Trust-categ- $2 \times$ Crisis & & & & $\begin{array}{l}-0.003 * \\
(0.002)\end{array}$ & $\begin{array}{l}-0.003 \\
(0.004)\end{array}$ & & & & \\
\hline Trust-categ- $3 \times$ Crisis & & & & $\begin{array}{l}-0.005 * * * \\
(0.002)\end{array}$ & $\begin{array}{l}0.002 \\
(0.003)\end{array}$ & & & & \\
\hline Constant & $\begin{array}{l}-0.070 * \\
(0.038)\end{array}$ & $\begin{array}{l}-0.065 \\
(0.040)\end{array}$ & $\begin{array}{l}-0.086 * * * \\
(0.021)\end{array}$ & $\begin{array}{l}-0.040 * \\
(0.022)\end{array}$ & $\begin{array}{l}-0.084 * * \\
(0.037)\end{array}$ & $\begin{array}{l}-0.123^{* *} \\
(0.051)\end{array}$ & $\begin{array}{l}-0.084 * * \\
(0.037)\end{array}$ & $\begin{array}{l}-0.050 * * \\
(0.021)\end{array}$ & $\begin{array}{l}-0.054 * * * \\
(0.020)\end{array}$ \\
\hline Firm-level controls & Yes & Yes & Yes & Yes & Yes & Yes & Yes & Yes & Yes \\
\hline Firm fixed effects & Yes & Yes & Yes & Yes & Yes & Yes & Yes & Yes & Yes \\
\hline Observations & 30,762 & 29,814 & 71,605 & 46,705 & 24,900 & 46,705 & 24,900 & 66,803 & 69,356 \\
\hline
\end{tabular}

